\title{
Los Karaimów podczas II wojny światowej. Kilka uwag historyka
}

\author{
Rafał Witkowski \\ Uniwersytet im. Adama Mickiewicza w Poznaniu \\ Wydział Historyczny
}

\section{The Fate of the Karaims during World War II. Some Remarks from a Historan}

\begin{abstract}
Summary: The policy of the German authorities, to, in accordance with Nazi ideology, annihilate the Jewish population constantly placed the Karaites, who at that time inhabited various European countries that were gradually being conquered by German armies, in constant danger. Official attempts made in 1938 by the representatives of Karaite community to convince the German authorities to treat them as a nonJewish population, resulted in only partial success. After the conquest of France, Lithuania and Crimea the Karaite community was persecuted in various ways. However, it succeeded in surviving the war, in contrast to the fate of most of European Jewry. This was only possible thanks to the efforts of numerous people, including hachan Seraya Shapshal.
\end{abstract}

Keywords: II World War, Karaims in France, Karaims in Lithuania, Karaims in Crimea; holocaust, Seraya Shapshal; German atrocities.

Prowadzone w wielu ośrodkach naukowych badania nad dziejami Karaimów zaowocowały opublikowaniem kilku rozpraw obejmujących okres drugiej wojny światowej, choć można z całym przekonaniem stwierdzić, że nie ukazała się do tej pory monografia, która traktowałaby o losie Karaimów w sposób kompleksowy i wyczerpujący. Wspólną cechą wszystkich tych opracowań jest 
to, że opisują one de facto doświadczenia Karaimów, akcentując wydarzenia w określonych obszarach (np. Rzesza ${ }^{1}$, Francja ${ }^{2}$, Polska-Litwa ${ }^{3}, \mathrm{Krym}^{4}$ ). Jednym z powodów takiego stanu rzeczy jest rozproszenie źródeł dotyczących poszczególnych krajów stopniowo zajmowanych przez wojska niemieckie lub radzieckie od wybuchu wojny we wrześniu 1939 r. Rysuje się zatem potrzeba przygotowania i krytycznego opublikowania swoistego zbioru dokumentów o dziejach Karaimów w okresie drugiej wojny światowej, dzięki któremu możliwe byłyby studia porównawcze 5 .

Takie skupienie uwagi na wydarzeniach w jednym regionie, np. na ziemiach litewskich (Troki, Wilno, Poniewież), czy na półwyspie krymskim, powoduje także, że piszący traci perspektywę czasową. Stosunek władz niemieckich, czy w niektórych przypadkach także radzieckich, do Karaimów był uwarunkowany

$1 \quad$ Philip Friedman, The Karaites under Nazi Rule, [w:] On the Track of Tyranny. Essays Presented by the Wiener Library to Leonard G. Montefiore, O.B.E. on the Occasion of his Seventieth Birthday, ed. Max Beloff, London 1960, s. 92-123.

2 Emanuela Trevisan-Semi, Gli ebrei caraiti tra etnia e religione, Roma, Carucci, 1984; tejże, Les Caraites: un autre: judaisme, Paris, Albin Michel, 1992; por. także artykuły dedykowane Karaimom tejże, Loscillation ethnique: le cas des Caraïtes pendant la Seconde Guerre mondiale, „Revue de l'Histoire des Religions”, t. 206 (1989), s. 377-398; tejże, The Image of the Karaites in Nazi and Vichy France Documents, „The Jewish Journal of Sociology”, t. 32/2 (1990), s. 81-93; tejże, A Brief Survey of Present-Day Karaite Communities in Europe, „The Jewish Journal of Sociology”, t. 33 (1991), s. 97-106; tejże, The Crimean Karaites as seen by the French Jewish Press in the Second Half of the Nineteenth Century, [w:] Proceedings of the Eleventh Word Congress of Jewish Studies, t. 3, Jerusalem 1994, s. 9-16.

3 Edward Tryjarski, Coming to the Rescue of the Karaims during the Second World War, „Rocznik Orientalistyczny”, t. 56 (2004), z. 2, s. 97-108; Hannelore Müller, Religionswissenschaftliche Minoritätenforschung: Zur religionshistorischen Dynamik der Karäer im Osten Europas, Wiesbaden 2010, tam edycja i zdjęcia kilku ważnych dokumentów dotyczących Karaimów w okresie drugiej wojny światowej oraz wcześniejsza literatura.

4 Warren P. Green, The Nazi Racial Policy towards the Karaites, „Soviet Jewish Affairs”, t. 8/2 (1978), s. 36-44; Kiril Feferman, The Fate of the Karaites in the Crimea during the Holocaust, [w:] Eastern European Karaites in the Last Generations. Edited by Dan D.Y. Shapira and Daniel J. Lasker, with the assistance of Golda Akhiezer and Mikhail Kizilov, Jerusalem 2011, s. 171-191.

5 Dla przykład, LMAVB F 143 zawiera kolekcję dokumentów związanych z działalnością hachana Seraji Szapszała, obejmującą 1616 jednostek inwentarzowych, z których znaczna część dotyczy wydarzeń w okresie drugiej wojny światowej. 
wieloma czynnikami, a już na pewno nie można traktować go jako stałej, planowej, przemyślanej i jednorodnej polityki. Tymczasem wydaje się, że władze niemieckie od samego początku miały problem z jednoznacznym określeniem swego stosunku do tak nielicznej - i małoznaczącej z perspektywy toczonej wojny - grupy ludności. W dokumencie z 5 stycznia 1939 r., na który później będą się często powoływać sami Karaimi, ale także przedstawiciele władz niemieckich, stwierdzono, że Karaimi nie są grupą wyznaniową, którą uznać trzeba za żydowską, ale ich przynależność rasowa nie została jasno zdefiniowana.

Przez większość historyków los Karaimów jest traktowany jako element składowy holokaustu, a nie szerzej - realiów wojny światowej, będącej tłem podjętego przez nazistów ostatecznego rozwiązania kwestii żydowskiej (Endlösung der Judenfrage). Skoro udało się Karaimom uniknąć tragicznego losu milionów europejskich Żydów, to czy zaiste nie należy uwzględnić w opisach dziejów podczas drugiej wojny światowej czynników innych, choć w oczywisty sposób powiązanych z losem Żydów. Stosunek władz nazistowskich do Żydów, Karaimów i wielu innych grup etnicznych i religijnych był następstwem rozwijanych na przestrzeni lat teorii rasowych, które doprowadziły do powstania Rassenkunde, rzekomo naukowego wyjaśnienia wyższości jednej rasy nad innymi ${ }^{6}$. Tymczasem analiza założeń nazistowskiej Rassenkunde oraz jej osiągnięć prowadzi do jednoznacznej konkluzji, że były to poglądy całkowicie nienaukowe, niespójne, nielogiczne, oparte o ideologiczne podstawy, a nie empiryczne przesłanki. Choć w okresie przed wybuchem wojny światowej antropologia opisywała rasy zdecydowanie innymi kategoriami niż współcześnie, kiedy szeroko rozumiane badania medyczne i biomedyczne zrewidowały wiele twierdzeń, to nawet w oparciu o ówczesny stan badań nad antropologicznym (kulturowym), czy stricte biologicznym uwarunkowaniem podziału na rasy nie pozwalała uczonym wolnym od nazistowskiej ideologii na postawienie takich tez, jakie głosili niemieccy „eksperci rasowi”. Doświadczyli tego także Karaimi, o których pochodzeniu, przynależności „rasowej” i religijnej wypowiadało się wielu niemieckich (i nie tylko) uczonych. W przypadku III Rzeszy ideologicznie motywowane pseudonaukowe poglądy rasowe stały się elementem systemu prawnego, zwłaszcza po uchwaleniu Ustaw Norymberskich i wprowadzeniu w życie kolejnych rozporządzeń władz niemieckich. By nadzorować przyjęte regulacje prawne, utworzone zostały w administracji państwowej urzędy często zmieniające swoją nazwę i zakres kompetencji, jak np. Urzędu Rzeszy do Spraw

6 Por. Robert Cecil, The Myth of the Master Race: Alfred Rosenberg and Nazi Ideology, London 1972. 
Badań Rasowych (Reichsstelle für Sippenforschung) oraz Ministerstwo Spraw Wewnętrznych Rzeszy (Reichsministerium des Inneren).

O skutkach niemieckich prześladowań Karaimów, których wówczas - wydaje się - władze nazistowskie traktowały jako Żydów, wiedzieli Karaimi nie tylko w Rzeszy. Pracujący w Berlinie rosyjski prawnik (Russischer Rechtsanwalt), dr A.W. Pisnjakow, zwrócił się listownie 12 czerwca 1936 r. do Seraji Szapszała (1873-1961), wówczas rezydującego w Trokach, z prośbą o pomoc ${ }^{7}$. Na wstępie wspomniał on o nieskutecznych próbach nawiązania kontaktu z karaimskim Hachanem wcześniej. Tym razem podjął próbę motywowany nowym niemieckim prawem dotyczącym ludności żydowskiej, jakie naziści wprowadzili. Pisnjakow wspomniał o wydarzeniach, kiedy w mieszkający w Niemczech Karaimi byli traktowani przez władze niemieckie w poszczególnych miastach jako Żydzi. Pisnjakow prosił Szapszała o jednoznaczne działania przeciwko takiemu traktowaniu, co mogłoby powstrzymać prześladowania. Nie jest znana bezpośrednia odpowiedź Szapszała na prośbę Pisnjakowa, ale przypuszczać można, że kolejne wydarzenia były powiązane z tego rodzaju apelami.

Kiedy nieliczna grupa Karaimów mieszkająca w III Rzeszy doświadczyła pierwszych skutków wprowadzenia w życie Ustaw Norymberskich, do władz niemieckich zwrócił się urodzony na Krymie Simon Douvan (Duwan, 1870-1957), który po zakończeniu pierwszej wojny światowej osiadł na emigracji we Francji. Przybył on z Paryża do Berlina i 5 września 1938 r. złożył w Ministerstwie Spraw Wewnętrznych Rzeszy zaopatrzoną w wyjaśnienie prośbę, by władze niemieckie nie traktowały Karaimów jako Żydów (lecz jako Nicht-Juden), a tym samym, by restrykcje prawne ich nie dotyczyły ${ }^{8}$. Bez wątpienia motywacje i okoliczności podjęcia starań przez Douvana zasługują na bliższe opisanie?.

7 LMAVB, F 143-1038, fol. 1r.

8 H. Müller, Religionswissenschaftliche Minoritätenforschung,, s. 131-133; Diemut Majer; "Non-Germans" under the Third Reich, The Nazi judicial and administrative system in Germany and occupied Eastern Europe with special regard to occupied Poland. 1939-1945, Baltimore-London-Washington 2003, s. 79-185, gdzie opublikowano akty prawne przyjęte do $1939 \mathrm{r}$.

9 Simon Douvan pochodził ze znanej krymskiej rodziny karaimskiej - jeden z jego przodków był hazzanem w Eupatorii. Tam też przed wybuchem rewolucji w $1917 \mathrm{r}$. Douvan mieszkał i pracowal, zajmując w latach 1906-1910 stanowisko burmistrza; por. H. Müller, Religionswissenschaftliche Minoritätenforschung, s. 135; por. też S. Duvan, Ja lûblû Evpatoriû. Slovo i delo Gorodskogo Golovy, Eupatoria 1996. 
Przypuszczać można, że nie bez znaczenia była wizyta Szapszała (i jego małżonki) latem 1937 r. w Paryżu, dokąd udali się, by zwiedzić wystawę światową ${ }^{10}$. Szapszał nawiązał także kontakty z tamtejszą społecznością karaimską, choć szczegóły tej wizyty i spotkań z francuskimi Karaimami nie były przez samego Szapszała nagłaśniane, jak też Douvan nie powoływał się na autorytet Szapszała, przywódcy religijnego Karaimów, w liście do władz niemieckich.

Kierujący wówczas działalnością Urzędu Rzeszy do Spraw Badań Rasowych (Reichsstelle für Sippenforschung, od 1940 r. - Reichssippenamt) Kurt Mayer (1903-1945) przekazał pismo Douvana do Wydziału I (Unterabteilung I), które nadzorował Christian Ulrich Freiherr von Ulmenstein. Już 7 września 1938 r. podanie to zostało przesłane do profesora Gerharda von Mende (1904-1964), turkologa i orientalisty związanego z uniwersytetem berlińskim i pracującego w tamtejszym Instytucie Spraw Rosyjskich (Rußland-Institut der Auslandshochschule) ${ }^{11}$. Von Mende uznawany był za jednego z najlepszych znawców języków tureckich. W swojej odpowiedzi datowanej na 7 października 1938 r., adresowanej do dyrektora Urzędu Rzeszy do Spraw Badań Rasowych wyraził swoją opinię, iż nie sposób jednoznacznie określić rasowego pochodzenia Karaimów ${ }^{12}$. Reichsstelle przesłało 20 października 1938 r. negatywną w swej wymowie opinię o piśmie Douvana do ministra spraw wewnętrznych Rzeszy (Reichsminister des Inneren). Z nieznanych powodów opinia urzędników ministerstwa była zgoła odmienna. Najpierw urzędnik ministerstwa (Ministerialdirigent) Hermann Hering (1874-?) podpisał stosowny dokument

10 LMAVB F 143-13: Dokumenty związane w pobytem S. Szapszała i jego żony we Francji (wystawa powszechna) w 1937 r.; Michel Kefeli, Karaimi we Francji, „Awazymyz”, z. 3 (2007); H. Müller, Religionswissenschaftliche Minoritätenforschung, s. 137.

11 Ingo Loose, Berliner Wissenschaftler im "Osteinsatz” 1930-1945. Akademische Mobilität zwischen Berliner Universität und Reichsuniversität Posen, [w:] Die Berliner Universität in der NS Zeit, Bd. 1: Strukturen und Personen, hrsg. von Christoph Jahr, Stuttgart 2005, s. 49-70 (tu, s. 62-67).

12 Gerhard von Mende stwierdził: „Zusammenfassend darf ich sagen, dass durch die der Eingabe von S. von Douvan beigegebenen Unterlagen der Nachweis der nichtjüdischen Herkunft der jüdischen Sekte der Karaimen in keiner Weise gegeben ist. Die Bezugnahme auf die Sprache und die russische Gesetzgebung ist nicht beweiskräftig. In der Frage, ob die Karaimen nach ihrer Herkunft Juden seien oder nicht, steht Meinung gegen Meinung, ohne dass ein gültiger Beweis ihrer nichtjüdischen Herkunft bisher erbracht wurde"; cytat za: H. Müller, Religionswissenschaftliche Minoritätenforschung, s. 134. 
22 grudnia 1938 r., a nieco później, 5 stycznia 1939 r., Ulrich von Ulmenstein wystosował oficjalną odpowiedź, stwierdzając, że:

„Die Sekte der Karaimen ist nicht als jüdische Religionsgemeinschaft im Sinne des $§ 2$ Absatz 2 der Ersten Verordnung zum Reichsbürgergesetz anzusehen. Die Feststellung, daß die Karaimen in ihrer Gesamtheit artverwandten Blutes sind, kann jedoch nicht erfolgen, denn die rassische Einordnung einer Person lässt sich nicht ohne weiteres nach ihrer Zugehörigkeit zu einem bestimmten Volke, sondern immer nur nach ihren persönlichen Abstammungsverhältnissen und rassebiologischen Merkmalen vornehmen. Die eingereichteil Unterlagen folgen anbei zurück."

Tych kilka stwierdzeń było później wielokrotnie cytowanych, choć przyznać trzeba, że biorąc pod uwagę istotę Ustaw Norymberskich, sukces Karaimów był połowiczny. Uznano jedynie wyznanie karaimskie jako nie-żydowskie, ale ich rasowe pochodzenia pozostało kwestią otwartą. Do tego właśnie w przyszłości będą odwoływać się władze niemieckie, prowadząc po zajęciu Francji w 1940 r. oraz Litwy i Krymu w 1941 r. dalsze dochodzenia w sprawie Karaimów. Należy także pamiętać, że tłem tych wydarzeń było wydalenie z Rzeszy tysięcy polskich Żydów w październiku 1938 r. oraz zniszczenie setek niemieckich synagog w nocy z 9 na 10 listopada 1938 r. $^{13}$

\section{Opinie naukowców o pochodzeniu etnicznym Karaimów}

Niewielka liczebnie społeczność karaimska była przedmiotem licznych badań antropologicznych, etnograficznych czy językoznawczych. Wśród polskich uczonych wspomnieć można prace Juliana Talko-Hryncewicza (1850-1936) ${ }^{14}$, czy Witolda Schreiber-Łuczyńskiego ${ }^{15}$. W 1929 r. szwajcarski etnolog Bruno

13 Por. Karol Jonca, The Expulsion of Polish Jews from the Third Reich in 1938, „Polin”, t. 8 (1994), s. 255-281; Jerzy Tomaszewski, Preludium zagłady: wygnanie Żydów polskich z Niemiec $w 1938$ roku, Warszawa 1998.

14 Julian Talko-Hryncewicz, Karaimi v. Karaici litewscy, [w:] Materiały Antropologiczno-Archeologiczne i Etnograficzne, t. 7, Kraków 1904, s. 44-100.

15 Witold Schreiber-Łuczyński, Badania nad antropologia dzieci chrześcijańskich, żydowskich i karaimskich $w$ Galicyi, Warszawa 1910 (Prace Towarzystwa Naukowego Warszawskiego. II. Wydział Nauk Antropologicznych, Społecznych, Historii i Filozofii nr 4); tegoż, Zur Anthropologie der Karaimkinder Galiziens, „Archiv für Anthropologie”, t. 9 (1910), s. 64-74. 
Adler pojechał do Eupatorii, gdzie prowadził badania wśród tamtejszych Karaimów $^{16}$. W okresie drugiej wojny światowej Karaimi często odwoływali się do książki Alexandre’a Baschmakoffa (1858-1943), urodzonego w Odessie rosyjskiego historyka, prawnika i etnologa ${ }^{17}$. Baschmakoff od 1924 r. mieszkał w Paryżu i utrzymywał kontakty z Serają Szapszałem, na którego ustalenia się powoływał. Być może nawet spotkali się podczas pobytu Szapszała w Paryżu. Wydaje się jednak, że najważniejsze z punktu widzenia władz niemieckich były prace Corrado Giniego (1884-1965), do którego władze niemieckie zwróciły się latem 1942 r. z prośbą o wyrażenie oficjalnego stanowiska w sprawie rasowej i religijnej przynależności Karaimów ${ }^{18}$.

Gini ukończył uniwersytet w Bolonii w 1905 r., a następnie rozpoczął swoją karierę akademicką na uniwersytetach w Cagliari (do 1913 r.), Padwie (do 1925 r.) i Rzymie, wykładając nauki polityczne, statystykę i ekonomię. W latach 1926-1932 pełnił obowiązki dyrektora włoskiego Istituto centrale di statistica (ISTAT). Jego początkowe zaangażowanie w ruch faszystowski stopniowo słabło, powracając do aktywności akademickiej, choć do końca drugiej wojny światowej nigdy nie zerwał oficjalnie z reżimem faszystowskim ${ }^{19}$. Dopiero po decyzji sądu w 1946 r. przywrócono mu prawo nauczania. Gini założył kilka znaczących czasopism naukowych, m.in. „Metron” w 1920 r. oraz „Genus” w 1934 r., będąc także autorem wielu znaczących prac naukowych ${ }^{20}$.

Jego naukowe zainteresowania uwzględniały szeroką gamę problemów, włączając w to biologiczne, demograficzne, statystyczne, społeczne i gospodarcze uwarunkowania rozwoju nowoczesnych narodów, kładąc fundamenty pod rozwój ekonometrii ${ }^{21}$. W latach trzydziestych przybył także do Polski i na Litwę,

16 Bruno Adler, Die Krim Karäer in geschichtlicher, demographischer und volkskundlicher Beziehung, „Bassler Archiv. Beiträge zur Völkerkunde”, R. 17 (1934), s. 103-133.

17 Alexandre Baschmakoff, Cinquante siècles d'évolution ethnique autour de la Mer Noire, Gembloux-Paris 1937.

18 LMAVB RS F 143-928, f. 1r-6r.

19 C. Gini, The scientific basis of fascism, „Political Science Quarterly”, t. 42 (1927), z. 1, s. 99-115.

20 C. Gini, I fattori demografici dell'evoluzione delle nazioni, Torino 1912; tegoż, Patologia economica, Milano 1924; Nascita, evoluzione e morte delle nazioni, Roma 1930; tegoż, Economia lavorista. Problemi del lavoro, Torino 1956; tegoż, Ricchezza e reddito, Torino 1959; tegoż, Questioni fondamentali di probabilità e statistica, Roma 1968.

21 Por. Corrado Gini: C. Benedetti, Ricordando Corrado Gini, „Rivista di Politica Economica”, t. 55 (1965), s. 371-377; G. Favero, Corrado Gini and Italian statistics under fascism, „Il Pensiero Economico Italiano”, t. 12 (2004), s. 45-59; V. Castellano, 
gdzie prowadził badania nad społecznością Karaimów. Wyniki ekspedycji Giniego - dziś już nie uznawane przez antropologów - mogły być rozumiane jako swoistego rodzaju odejście od głównego nurtu ideologicznych badań prowadzonych wśród włoskich uczonych o faszystowskich poglądach rasowych ${ }^{22}$. Po kilku latach, kiedy wybuchła druga wojna światowa, a nazistowskie Niemcy przystąpiły do „ostatecznego rozwiązania kwestii żydowskiej”, wyniki badań Giniego, podważające „rasowe” związki Karaimów i Żydów, nabrały zupełnie innego znaczenia.

Przyjazd do Polski poprzedziła korespondencja między Corrado Ginim a Serają Szapszałem ${ }^{23}$. Hachan Karaimów odnosił się do projektu Giniego z rezerwą, nie angażując się bezpośrednio w prowadzone przez Włocha badania ${ }^{24}$. Oficjalnie pobyt między sierpniem a październikiem 1934 r. został przeprowadzony pod auspicjami "Comitato Italiano per lo Studio dei Problemi della Popolazaione”. W trakcie tych kilkunastu tygodni zespół Corrado Giniego przebadał 549 osób w pięciu miejscowościach (Wilno, Troki, Halicz, Łuck, Poniewież). Według analiz Giniego Karaimi dzielili się na trzy odrębne grupy: I) Karaimów orientalnych, mieszkających w Stambule, Kairze i Jerozolimie,, 2) Karaimów krymskich, których przodkami byli Chazarowie i 3) słowiańskich Karaimów (Kozaków kubańskich), mieszkających na północnym Kaukazie.

Corrado Gini: a memoir, „Metron”, t. 24 (1965), s. 3-84 (tam pełna bibliografia prac badacza); Giovanni Maria Giorgi, Bibliographic portrait of the Gini concentration ratio, „Metron”, t. 48 (1990), s. 183-221; tegoż, Il rapporto di concentrazione di Gini: genesi, evoluzione ed una bibliografia commentata, Siena 1992; tegoż, Gini's scientific work: an evergreen, „Metron”, t. 63 (2005), s. 299-315; tegoż, Corrado Gini: the man and the scientist, „Metron”, t. 69 (2011), s. 1-28; tegoż, The Gini inequality index decomposition. An evolutionary study; w: The measurement of individual well being and group inequalities. Essays in memory of Z.B. Berebi, ed. J. Deutsch, J. Silber, Abingdon 2011, s. 189-222; tegoż, Corrado Gini. Il Contributo italiano alla storia del Pensiero, [w:] Economia (Ottava appendice), Roma 2013, s. 620-626; Daniela Parisi, Corrado Gini (1884-1965): The Leading Figure of the Italian Group in the Econometric Society, „History of Political Economy”, t. 43 (2011), s. 211-232.

22 F. Cassata, Il fascismo razionale. Corrado Gini fra scienza e politica, Roma 2006, s. 140.

23 LMAVB RS F 143-116: Kopie siedmiu listów do Corrado Gini z lat 1934-1935; pozostałe listy znajdują się w Archiwum Akt Nowych w Warszawie.

24 LMAVB RS, F 143-116, fol. 1r (brudnopis listu do prof. Corrado Giniego w związku z jego planami przyjazdu do Polski, Wilno, 8 czerwca 1934 r.); LMAVB RS, F 143-116, fol. 2r-2v (brudnopis listu do prof. Corrado Giniego w związku z jego planami przyjazdu do Polski; Wilno, 12 lipca 1934 r.); por. artykuł Marioli Abkowicz w tym numerze „Almanachu Karaimskiego”. 
Wśród Karaimów krymskich wyróżnił dwie podgrupy: Karaimów polsko-litewskich i Karaimów krymskich. Rezultaty swoich analiz opublikował w 1936 r. na łamach czasopisma "Genus”25.

Jednym z powodów, dla których wielu uczonych chciało wszechstronnych badań Karaimów, był fakt, że grupa ta od wieków pozostawała w znacznym stopniu odizolowana od otoczenia ${ }^{26}$. W relacji jednego z najwybitniejszych polskich antropologów - Jana Czekanowskiego - Karaimi wiele zawdzięczają rezultatom badań dra Michała Reichera, profesora Uniwersytetu Stefana Batorego, wobec którego „Karaimi mają zupełnie szczególne zobowiązania. Wyniki naszych badań umożliwiły bowiem Karaimom przetrwanie ostatniej burzy dziejowej w latach 1940-1944. Były bowiem te wyniki tak przekonywujące, że Niemcy, jakkolwiek czerpali wiadomości z przestarzałego artykuliku w Encyklopedii Brockhausa, gdzie niesłusznie określono Karaimów jako sektę żydowską, powstałą w VIII wieku w Babilonie, dali się wreszcie jednak przekonać, że w Polsce wyznawcami tej pierwotnie semickiej religii jest obecnie już nieliczny szczep turecki o wielkiej przeszłości historycznej”27. Wyniki swoich badań zaprezentował dr Michał Reicher podczas Zjazdu Polskich Lekarzy i Przyrodników w 1932 r. w Poznaniu ${ }^{28}$. Jak pisał Czekanowski, „opierając się na wynikach badań Reichera, jak widzimy, bez trudu możemy wykazać, że Karaimi stanowią formację różniącą się zasadniczo od formacji europejskich"29.

25 Corrado Gini, I Caraimi di Polonia e di Lituania, „Genus”, 14/2 (1936), s. 1-56; por. S. Szapszał, [rec.] C. Gini, I Caraimi di Polonia e di Lituania, Genus, II, Roma 1936, s. 1-56; „Myśl Karaimska”, z. 12 (1939), s. 111-112; H. Müller, Religionswissenschaftliche Minoritätenforschung, s. 143-145; wypowiadając się o ekspedycji Corrado Giniego, Czekanowski stwierdził - słusznie - że „było to zdjęcie antropologiczne zakrojone na wielką skalę, którym chciano objąć wszystkich w ogóle Karaimów, przy czym kładziono wielki nacisk na badania serologiczne. Niestety włoscy członkowie ekipy badawczej nie posiadali szczególnych kwalifikacji naukowych i w całym przedsięwzięciu panował duch biura statystycznego, pracującego mechanicznie”; por. Jan Czekanowski, Z zagadnień antropologii Karaimów, „Myśl Karaimska”, seria nowa, t. 2 (1946-1947), s. 20.

26 J. Czekanowski, Z zagadnień antropologii Karaimów, s. 3.

27 tamże, s. 3; warto także wspomnieć o tłumaczeniach na język niemiecki publikacji, które ukazywały się w okresie przedwojennym. W Wilnie w 1938 r. Szymon Firkowicz opublikował broszurkę pt. O Karaimach $w$ Polsce, a jej tłumaczenie jako S. Firkowicz, Die Karaimen in Polen przygotował H. Cosack (Berlin 1941).

28 J. Czekanowski, Z zagadnień antropologii Karaimów, s. 21.

29 tamże, s. 9. 
Zresztą sam Czekanowski, opierając się na własnych badaniach, a także analizach Salomona Czortkowera ${ }^{30}$, doszedł do konkluzji, że „przytoczone tu wyniki pozwalają na krytyczne ustosunkowanie się do dosyć rozpowszechnionego twierdzenia, że wielkie skupienie Żydów w Europie Południowo-Wschodniej jest w znacznej mierze konsekwencją wchłonięcia przez nich szczątków tureckiego (huńskiego) szczepu Chazarów wyznających mozaizm. Otóż skład antropologiczny dawnych Żydów ukraińskich, reprezentowanych przez najuboższą warstwę ludności żydowskiej Lwowa, pozwala na branie w rachubę takiej tureckiej domieszki. Musiała to być jednak domieszka drobna, skoro nie zaznaczyła się podniesieniem odsetka składnika laponoidalnego. Zarysowuje się ona natomiast wyraźnie u Karaimów, uważających się za potomków Chazarów"31.

Najciekawszy jest chyba fragment w relacji Czekanowskiego, kiedy tenże odnosił się do wydarzeń z czasów wojny ${ }^{32}$ :

„W dyskusji przeprowadzanej z Niemcami w r. 1942 we Lwowie nie podnosiłem oczywiście tych wątpliwości, a podkreślałem natomiast, że przepojenie Karaimów krwią Alanów stanowi dowód, iż ci epigoni Scytów nie odpłynęli w całości ze stepów na Kaukaz, lecz częściowo zostali, wchłonięci przez najazd szczepów tureckich i to tłumaczyłoby nam teraźniejszą „tatarszczyznę” Karaimów. Na fakt ten zwracałem szczególną uwagę przez wzgląd na stosunek Niemców do Tatarów, jako do części Muzułmańskiego Wschodu. Z tych samych względów identyczne stanowisko zajął ówczesny naczelnik lwowskiej ekspozytury Ostinstytutu, Doc. Dr Hans Niemann, Ślązak z okolic Niemczy, urodzony co prawda, w Hamburgu, za swoje kontakty z Polakami zesłany w charakterze prostego szeregowca na front włoski, skąd przeszedł do Wojska Polskiego.

Druga sprawa również nie całkiem jasna, to zagadnienie ewentualnej niezmienności składu rasowego Karaimów, spowodowanej ich izolacją biologiczną. Otóż rzeczywiście od stuleci Karaimi nie wchłaniali u nas krwi obcej, poza stosunkowo nielicznymi związkami małżeńskimi, zawieranymi z Karaimami krymskimi. Tracili oni jednakowoż dosyć dużo ludzi uzdolnionych wskutek tego, że korzystając dawniej w Rosji z przywilejów ludności prawosławnej dochodzili tam do stanowisk i żenili się z chrześcijankami. Były to jednostki dla wspólnoty

30 Salomon Czortkower, Anthropologische Struktur der Juden, „Anthropologischer Anzeiger”, R. 9 (1932), s. 250-263; tegoż, Pochodzenie i struktura rasowa Karaimów, „Przegląd Antropologiczny”, t. 12 (1938), s. 678-680; w swych poszukiwaniach Czortkower opowiedział się za hipotezą, że Chazarowie przyjęli mozaizm w wersji karaimskiej.

31 Jan Czekanowski, Człowiek w czasie i przestrzeni, Warszawa, PWN, 1967, s. 259.

32 tamże, s. 21. 
karaimskiej stracone i te straty, przymałej liczebności Karaimów, mogłyby powodować przesunięcia w składzie rasowym, gdyby pewne składniki wykazywały wyraźniejszą tendencję do dezertowania z karaimskiego partykularza”.

Opierając się ówczesnych metodach prowadzenia badań antropologicznych, Czekanowski ${ }^{33}$ zestawił wyniki badań o Czuwaszach, Karaimach krymskich (Zabołotny), Tatarach kazańskich (Schwartz-Nimczowicka), turecko-języcznych Krymczakach, aszkenazyjskich Żydach polskich i rosyjskich oraz o innych grupach etnicznych ${ }^{34}$, dochodząc do konkluzji, że Karaimi i Żydzi reprezentowali dwa biegunowo odmienne regiony pod względem serologicznym: Żydzi reprezentowali kontynent europejski, zaś Karaimi - Azję. Badając szczegółowo populację samych Karaimów Czekanowski ustalił, że można wśród nich wyodrębnić trzy grupy: 1) polską (czy raczej geograficznie rzecz ujmując litewsko-polsko-ukraińską), 2) krymską oraz 3) egipską, z których każda wykazywała odmienne struktury antropologiczne, powstałe w skutek wchłaniania ludności obcej o bardzo odmiennym składzie rasowym. Opowiedział się także jednoznacznie przeciwko lansowanej tezie o chazarskim pochodzeniu Karaimów, stwierdzając, że (...) „nie może być mowy o tym, by Karaimi, tak polscy, jak i krymscy, byli pod względem antropologicznym identyczni z Chazarami. Różnili się od nich bowiem zasadniczo przemieszką składnika orientalnego, charakterystycznego dla Semitów”. Czekanowski uważał, że widoczne były „komponenty wywodzące się z Babilonii z VIII w., gdzie rodziło się wyznanie”.

33 Por. Jan Czekanowski, Z zagadnień antropologii Karaimów.

34 W swoich poszukiwaniach Jan Czekanowski odwoływał się do prac: Constantin Ikow, Neue Beitrage zur Anthropologie der Juden, „Archiv für Anthropologie”, t. 15 (1884), s. 369-378; Michał Reicher, Sur les groupes sanguines des Caraïmes de Troki et de Wilno, „Anthropologie”, t. 19, Praha 1932, s. 259-267; tegoż, Grupy krwi u Karaimów Trockich $i$ Wileńskich, [w:] Pamiętnik XIV Zjazdu Lekarzy i Przyrodników Polskich w Poznaniu, Poznań 1933, s. 389-390; J. Talko-Hryncewicz, Karaimi v. Karaici Litewscy, „Materiały Antropologiczno-Archeologiczne i Etnograficzne”, t. 7 (1904), s. 44-100; Samuel Weissenberg, Die Jemenitischen Juden, „Zeitschrift für Ethnologie”, t. 41 (1909), s. 309-327; tegoż, Karaimy i Krymčaki s antropologičeskoj točki zrenija, „Russkij Antropologičeskij Žurnal”, t. 8 (1912), nr 4, s. 38-56; S.S. Zabolotnyj, Die Blutgruppen der Karaimen und Krimtschaken; na postawie recenzji St. Wurzingera, drukowanej w „Anthropologischer Anzeiger”, R. 6 (1929), s. 128. 


\section{Prasa niemiecka o Karaimach}

W latach wojny ukazało się kilkanaście artykułów w prasie niemieckiej o Karaimach, które z jednej strony były odbiciem poglądów władz niemieckich, a z drugiej rozpowszechniały wiedzę o tej grupie etnicznej, zazwyczaj przychylną Karaimom, w okresie tak głębokich przemian. Jednym z nich był tekst opublikowany w 1943 r. przez Herberta Kirrinnisa (1907-1977). Urodzony w Prusach Wschodnich, zdobywał wiedzę na uniwersytetach w Marburgu i Królewcu, gdzie studiował historię, geografię i języki nowożytne. Od 1933 r. pracował jako nauczyciel w szkole średniej (Mittelschule) w Tylży (Tilsit). W 1939 r. został wcielony do armii niemieckiej i stacjonował, m.in., w Wilnie. Naukowo interesował się stosunkami niemiecko-litewskimi na przestrzeni wieków ${ }^{35}$ oraz historią miast w Prusach Wschodnich. Te ostatnie prace ukazały się już po wojnie, kiedy osiadł w Niemczech Zachodnich ${ }^{36}$. Z treści artykułu o Karaimach wynika jednoznacznie, że niezbędne informacje Kirrinnis uzyskał od Seraji Szapszała, popularyzując karaimski pogląd o ich pochodzeniu etnicznym i istocie religii karaimskiej ${ }^{37}$. Opinie prasy niemieckiej, zważywszy na fakt całkowitej kontroli na nią ze strony nazistów w latach wojny, zasługują na osobne opracowanie.

\section{Karaimi we Francji}

Społeczność karaimska we Francji różniła się znacznie od swoich współwyznawców, mieszkających w Polsce, Litwie i na Krymie. Przede wszystkim tworzyli ją emigranci polityczni, których prawny status nie zawsze musiał być uregulowany. Byli oni we Francji grupą nową, która pojawiła się po pierwszej wojnie światowej, a tym samym stopień ich akulturacji czy asymilacji z Francją był wyraźnie inny, niż w przypadku Karaimów z ziem wchodzących w skład państwa polskiego, litewskiego, czy ZSRR.

W 1926 r. grupa „białych Karaimów”, którzy opuścili Rosję i osiedlili się w Paryżu, założyła Stowarzyszenie Karaimów w Paryżu (Association des Karaïmes à Paris), które przez lata pozostawiało główną organizacją zrzeszającą

35 H. Kirrinnis, Russische Bevölkerungszahlen zu Ende des 18. Jahrhunderts nach dem Tabellenwerk von Johann Friedrich Storch, Riga 1795, „Geographische Zeitschrift”, t. 50 (1944), s. 124-128; tegoż, Wilna, „Zeitschrift für Erdkunde”, R. 12 (1944).

36 Np. H. Kirrinnis, Geschichte der Friedrichsschule zu Gumbinnen. Ein Beitrag zur Kulturund Bildungsgeschichte Ostpreussens, Würzburg 1963 (seria: Ostdeutsche Beiträge aus dem Göttinger Arbeitskreis, t. 26).

37 H. Kirrinnis, Die Karaimen, „Petermanns Geographischen Mitteilungen”, z. 3-4 (1943), s. 100-101. 
francuskich Karaimów. Na czele Stowarzyszenia stał Simon Kazas. Po przegranej wojnie z Niemcami w 1940 r. Francja została podzielona na dwie strefy okupacyjne, a Karaimi, mieszkający głównie w kontrolowanym przez Niemców Paryżu, musieli rozpocząć walkę o uznanie ich przez władze okupacyjne za nie-Żydów (Nicht-Juden). Wkrótce po zakończeniu działań wojennych, 2 czerwca 1941 r. władze niemieckie wydały Statut des Juifs (Statut żydowski), który obowiązywał najpierw w niemieckiej strefie okupacyjnej, a w październiku 1941 r. utworzyły Zarząd Spraw Żydowskich (Commissariat Général aux Questions Juives). Dnia 29 listopada 1941 r. Stowarzyszenie Karaimów w Paryżu przedłożyło władzom niemieckim dwunastostronicowe memorandum, w którym wyjaśniało powody, dla których Karaimi nie powinni być uznawani za Żydów. Oficjalna odpowiedź została jednak wydana dopiero w lutym 1943 r.!

Simon Kazas zacytował kilka dokumentów wspierających stanowisko Stowarzyszenia, w tym: I) dekret cara Aleksandra II z 8 kwietnia 1863 stwierdzający, że Karaimi w Rosji powinni być traktowani jako rosyjscy mieszczanie, 2) dekret rosyjskiego premiera Piotra Arkadjewicza Stołypina (1862-1911), który 5 kwietnia 1910 polecił wszystkim gubernatorom i urzędnikom państwowym, by traktowali Karaimów jako osobną grupę religijną i etniczną, nieżydowską, 3) opinie zwierzchników rosyjskiej Cerkwi Prawosławnej na wygnaniu - metropolity Eulogiusza z 5 listopada 1941 r. i biskupa Serafima z 10 listopada 1941 r., fragmenty książki Alexandre’a Baschmakoffa, hasła z różnych encyklopedii (np. Encyclopédie de l'Islam, Jewish Encyclopedia), fragmenty z książki Lazara Krasnosselsky'ego ${ }^{38}$, baronowej L. Wrangel ${ }^{39}$, wyniki badań Corrado Giniego i inne dokumenty. W opinii Simona Kazasa Karaimi należeli do grupy etnicznej, którą on określał mianem Tauro-Crimmeriens turquisés. Podkreślił także, że wielu Karaimów służyło w armii generała Piotra Mikołajewicza Wrangla (1878-1928), walcząc z bolszewikami ${ }^{40}$.

Według władz francuskich pod koniec $1941 \mathrm{r}$. w niemieckiej strefie okupacyjnej we Francji przebywało ok. 270 Karaimów, z czego ok. 200 w Paryżu. Dane te są zbieżne z ustaleniami Seraji Szapszała, które później cytował m.in. Corrado Gini, że w okresie od wybuchu rewolucji bolszewickiej do zakończenia

38 Leizar Krasnosselsky, Zur Geschichte der Karäer im russische Reiche. Inaugural-Dissertation der hohen philosophischen Fakultät der Universität Bern zur Erlangung der Doktorwürde, Bern 1912.

39 Lioudmila Sergeevna Wrangel (Bonne), Visages de Crimée. Illustrations de Serge de Wrangell, Paris 1939, s. 75-79.

40 Kazas powoływał się na badania Paula Ernsta Kahlego (1875-1964), niemieckiego orientalisty, który wyemigrował do Anglii w 1939 r.; por. H. Müller, Religionswissenschaftliche Minoritätenforschung, s. 146. 
wojny domowej (1917-1922) z Rosji uciekło 447 Karaimów, z których 268 osiedliło się we Francji, 46 w Rumunii, 42 w Turcji, 35 w Bułgarii, 8 w Niemczech, $7 \mathrm{w}$ Egipcie i jeden w Syrii ${ }^{41}$.

Dwóch wspomnianych hierarchów Cerkwi Prawosławnej było dobrze znanych w kręgach rosyjskich emigrantów na Zachodzie. Eulogiusz (Wasilij Semionowicz Georgijewski; 1868-1946) był biskupem rezydującym po rewolucji bolszewickiej w Paryżu, a od 1931 r. stał na czele egzarchatu Cerkwi Rosyjskiej w Europie Zachodniej. Serafim (Aleksander Jonnowicz Lukjanow; 1879-1959) był arcybiskupem prawosławnym w Finlandii (1921-1923). W 1926 r. opuścił ten kraj i udał się do Londynu i Paryża, gdzie do 1949 r. sprawował godność egzarchy Cerkwi Prawosławnej podległej patriarchatowi w Moskwie. W 1954 r. powrócił do Związku Radzieckiego i osiadł w 1959 r. w klasztorze w Mołdawii ${ }^{42}$.

\section{Karaimi na ziemiach litewskich}

Po zajęciu ziem litewskich przez wojska niemieckie w czerwcu 1941 r. władze okupacyjne przystąpiły do organizacji nowej administracji, częściowo pozwalając Litwinom na przejęcie kontroli nad niektórymi przestrzeniami życia społecznego. Najważniejsze jednak decyzje i tak podejmowali przedstawiciele władz niemieckich (cywilnych i wojskowych), które funkcjonowały w ramach Komisariatu Rzeszy dla Ziem Wschodnich (Reichskommisariat für Ostland) z siedzibą w Kownie, później przeniesioną do Rygi. Komisariat Wschód dzielił się na cztery okręgi (Generalbezirke): Estonia (Estland), Łotwa (Lettland), Litwa (Litauen) oraz Białoruś (Weissruthenien). Komisariat wchodził w skład Ministerstwa Rzeszy do Spraw Okupowanych Ziem Wschodnich (Reichsminisa terium für die besetzten Ostgebiete), na czele którego stanął Alfred Rosenberg (1893-1946). Podstawowym celem działań władz niemieckich było wprowadzenie w życie Generalnego Planu Wschodniego (Generalplan Ost), którego założenia w trakcie wojny ulegały modyfikacjom.

${ }^{41}$ H. Müller, Religionswissenschaftliche Minoritätenforschung, s. 147; E. Trevisan-Semi, The Image of the Karaites in Nazi and Vichy France. Documents, "Jewish Journal of Sociology”, t. 32/2 (1990), s. 81-93; Michael R. Marrus, Robert O. Paxton, Vichy France and the Jews, New York 1981; Gerd Stricker, Die Geschichte der russischen orthodoxen Kirche in der Diaspora, Berlin 2009, s. 34-66; Abraham Asher, Prime Minister P. A: Stolypin and his "Jewish" Advisors, "Journal of Contemporary History”, t. 30 (1995), s. 513-532; E. Trevisan-Semi, Les Caraites. Un autre judaisme, Paris 1992.

42 Harvey Fireside, Icon and Swastika. The Russian Orthodox Church under Nazi and Soviet Control, Cambridge 1971. 
Przedstawiciele Komisariatu Rzeszy Litwa (Reichskommissariat Litauen) wielokrotnie nawiązywali kontakty z zwierzchnikami społeczności karaimskiej, które przybierały różne formy ${ }^{43}$. Dnia 31 sierpnia 1941 r. Adrian von Renteln, komisarz Rzeszy na Litwie (Generalkommissar von Litauen) wysłał swoich współpracowników, by przeprowadzili rozmowy z Serają Szapszałem oraz Szymonem Firkowiczem. Już 1 września 1941 r. Werner Essen, Hauptabteilungsleiter, wysłał raport z tego spotkania, w którym wspomniał, że w Trokach żyło ok. 300 Karaimów, w całej Litwie ok. 600-700, na Krymie ok. 15 000, w Turcji i Egipcie ok. 7 000-8 000. W jego opinii Szapszał i Firkowicz, ,in reinem Russisch ohne jede Beimischung von Jargon (jiddisch) sprachen”, zaś języka niemieckiego nie rozumieli wcale ${ }^{44}$. Jednym z podstawowych zagadnień, jakie interesowały władze niemieckie były ewentualne powiązania między Karaimami a Żydami, np. małżeństwa mieszane, ale szybko ustalono, że Żydzi i Karaimi trzymali się osobno i takich związków de facto nie było ${ }^{45}$.

Tłem dla nich pozostawała przez wiele miesięcy niemiecka polityka eksterminacji Żydów, która od czerwca do grudnia 1941 r. przyniosła śmierć tysięcy ludzi ${ }^{46}$.

Na potrzeby niemieckich władz okupacyjnych społeczność Karaimów mieszkająca na terenie Litwy musiała przygotować odpowiedzi na kwestionariusz dotyczący finansowej struktury wyznań, związków i zgromadzeń religijnych (Frageboden betreffend die finanzielle Struktur der kirchlichen Konfessionen, Verbande und Vereinigungen). Kwestionariusz ten był dokumentem sporządzonym w językach polskim i niemieckim. Zachowana kopia została wypełniona ręcznie, niekiedy po polsku, niemiecku lub litewsku. Frageboden nie został dokładnie datowany, ale można przyjąć, że został przygotowany w pierwszych miesiącach okupacji w 1941 r. Według tego zestawienia karaimska gmina w Poniewieżu (Panevėžys) liczyła 132 członków, duchowny (hazzan) otrzymywał wynagrodzenie roczne w wysokości 1200 Lt, a sługa świątynny - 300 Lt rocznie. Drewniana kienesa została zbudowana w 1858 r. i odnowiona w 1939 r. ${ }^{47}$ Podobnie, gmina karaimska w Wilnie liczyła 227 członków, duchowny otrzymywał 347 Lt

43 Dla władz niemieckich przygotowywane były wykazy członków gmin karaimskich; por. LMAVB F 143-1070 Spis Karaimów w Trokach, Wilnie i Poniewieżu (1939-1940?); F 143-1080 Wykaz członków karaimskiej gminy wileńskiej (1942).

$44 \quad$ H. Müller, Religionswissenschaftliche Minoritätenforschung, s. 149.

45 H. Müller, Religionswissenschaftliche Minoritätenforschung, s. 152-153.

46 Z bogatej literatury por. Josifas Levinsonas, Holokaustas Lietuvoje, Vilnius, 2004; Arūnas Bubnys, Holokaustas Lietuvoje 1941-1944 m, Vilnius 2011.

47 LMAVB, F 143-854, fol. 38r. 
(rocznie?), a sługa świątynny - 100 Lt (rocznie?). Murowana kienesa została wzniesiona w latach $1912-1923^{48}$. Trzeci kwestionariusz dotyczy gminy w Trokach, która liczyła 272 członków, duchowny otrzymywał 225 zł, sługa świątyni - 150 zł, zaś drewniany dom modlitwy został zbudowany w 1802 r. ${ }^{49}$.

W kwietniu 1942 r. Szapszał odpowiedział na zapytanie skierowane przez władze niemieckie w Kownie o liczbę dzwonów używanych do celów sakralnych. W wyjaśnieniu Szapszał stwierdził, że Karaimi nie używali żadnych dzwonów i dlatego żaden nie podlegał konfiskacie ${ }^{50}$.

Kilka miesięcy później, niemiecki komendant Wilna (Gebietskommissar der Stadt Wilna) polecił, by 4 września 1942 r. Seraja Szapszał stawił się następnego dnia o godzinie 10.00 rano w jego biurze, celem omówienia kwestii związanych ze statusem karaimskiej gminy wyznaniowej (Satzungen der karaimischen Religionsgemeinde $)^{51}$. Takiego rodzaju spotkania były inicjowane przez władze niemieckie. Dla nich Szapszał przygotowywał także wyjaśnienia dotyczące religii karaimskiej i etnicznego („rasowego”) pochodzenia Karaimów. Niekiedy przybierały one formę krótkich, kilkustronicowych pism, innym znów razem wyczerpujących opracowań religioznawczych ${ }^{52}$. Prowadził także korespondencję w sprawach dotyczących Karaimów ${ }^{53}$.

48 LMAVB, F 143-854, fol. 40r.

49 LMAVB, F 143-854, fol. 43r.

50 LMAVB, F 143-854, fol. 20r.

51 LMAVB, F 143-845, fol. 17r.

52 Większość z tych opracowań została przygotowana w języku niemieckim dla władz okupacyjnych; por. LMAVB F 143-845: Seraja Schapschal, Die Stellung der karaimischen Konfession under anderen monotheistischen Bekenntnissen; F 143-846: Seraia Schapschal, Die Abstammung der Krimer und Litauischen Karaimen, inne kopie i tłumaczenia znajdują się w F 143-847, f. 1r-4r (Die Stammung der Krimer und Litauischer Karaimen), f. $5 r-8$ r (O plemennom proischoždenii Karaimov), f. 15r-17r (Miejsce wyznania karaimskiego pośród innych monoteistycznych religii (ros.); f. 18r-19v (Miejsce wyznania karaimskiego pośród innych monoteistycznych religii (pol.); f. 20r-23r (Die Stellung der karaimischen Konfession unter anderen monotheistischen Bekenntnissen, Wilna, den 23. April 1942); F 143-899: Seraia Schapschal, Die glaubenslehre der Karaer. Die Khasaren, (1942-1943, kart 80); jak i wiele innych podobnych pism, które nigdy nie były przedmiotem analizy pod względem teologicznym.

53 Seraja Szapszał prowadził bogatą korespondencję dotyczącą Karaimów i ich losów wojennych: F 143-1053 (o Karaimach w Berlinie z lat 1936v-1944); F 143-1057 (różne dokumenty o Karaimach z lat 1937-1944); F 143-1081 (sprawy dotyczące Karaimów w trakcie wojny z r. 1942; F 143-1082 (korespondencja S. Szapszala z lat 1942-1943), F 143-1084 (sprawy dotyczące Karaimów w 1943 r.); F 143-1085 (sprawy dotyczące 
Hachan Seraja Szapszał niekiedy był proszony o zajęcie stanowiska w niezwykle delikatnych (i złożonych) kwestiach, biorąc pod uwagę realia wojny, poruszanych przez Niemców. W liście z 10 listopada 1943 r. niejaki Johannes Jacob, architekt i budowniczy zamieszkały w Stahnsdorf (Teltow) ${ }^{54}$, zwrócił się do hachana Karaimów z prośbą o pomoc w wyjaśnieniu pochodzenia nazwiska (a tym samym „rasowej” przynależności) jego teściowej. Jacob przeczytał artykuł w gazecie „Deutsche Allgemeine Zeitung”, w którym Bergeman opisał w zwięzły sposób historię litewskich Karaimów i wspomniał językoznawcze zainteresowania Szapszała. Z tego powodu zwrócił się z prośbą o wyjaśnienie pochodzenia nazwiska jego teściowej (Schwiegermutter) pochodzącej z Wilna, która nazywała się Tatjana Akjimowna Paperne, jej ojciec nosił nazwisko Akjim Fjodorow Paperne, a matka - Isabella Wassilowna Paperne, z domu Bogoslav. Byli oni wyznania katolickiego. Jacob przypuszczał, choć nie wiadomo, na ile sam poważnie traktował tę opinię, że nazwisko Paperne pochodzi od włoskiego Paparini albo Paperini, choć był także świadom, że wielu Żydów wileńskich mogło nosić takie nazwiska. Jacob wspomniał przy tym o licznej emigracji z Włoch, która w minionych wiekach osiedlała się w Wilnie i przyczyniała do budowy gmachów w stylu barokowym. Odpowiedź Seraji Szapszała, jeśli w ogóle została wysłana do Johannesa Jacoba, pozostaje nieznana.

Litewskie władze odpowiedzialne za samoobronę (Lietuvos Generalinès Srities Socialinio Draudimo İstaiga) wydały 29 stycznia 1944 r. zarządzenie dla wszystkich podległych jednostek (Visioms Socialinio Draudimo İstaigoms), stwierdzając w nim, że Karaimi nie powinni być traktowani jako Żydzi, ponieważ przynależą do rasy „środkowoazjatyckiej” i „bliskowschodniej”. Ponadto powinni być chronieni jak wszyscy inni mieszkańcy ziem litewskich ${ }^{55}$.

Drugim, niezwykle istotnym dla Karaimów obszarem, który został w 1941 r. zajęty przez wojska niemieckie i ich sojuszników, był Krym. Zanim armia niemiecka dotarła do Krymu i po ciężkich walkach zajęła półwysep, Ukraina doświadczyła masowych mordów na ludności żydowskiej, przeprowadzanych od pierwszych dni wojny, których skutkiem była całkowita zagłada większości

Karaimów w latach 1943-1944); F 143-1527 (pismo z 28 lipca 1943 r. do przewodniczącego gminy karaimskiej w Berlinie z Symferopola w sprawie jego córki Tamary, zmobilizowanej do pracy w Niemczech).

54 LMAVB, F 143-1038, fol. 98r.

55 LMAVB, F 143-1085, fol. 3r: Reicho Komisaro patvarkymu karaimai savo prigimtimi yra Artimosios ir Vidurinés Azijos rasés ir žydams neprilyginami. Jie turi būti draudžiami kaip vietiniai gyventojai. 
ukraińskich Żydów ${ }^{56}$. Wraz z Żydami zginęli także w trakcie masowych rozstrzeliwań w Babim Jarze niektórzy kijowscy Karaimi ${ }^{57}$.

\section{Karaimi na Krymie}

W planach nazistów wyrażonych przez Hitlera podczas wystąpienia 16 lipca 1941 r. ludność półwyspu krymskiego miała być wysiedlona, a następnie Krym miał zostać skolonizowany przez Niemców z Rumunii lub południowego Tyro$\mathrm{lu}^{58}$. Znane już były przyszłe nowe nazwy „niemieckich” krymskich miast - Symferopol miał nosić nazwę Gotenberg, a Sewastopol - Theodorichshafen ${ }^{59}$. Jednak wraz z rozwojem sytuacji na froncie wschodnim, postępem armii niemieckiej w kierunku Kaukazu i przewartościowaniem politycznych kalkulacji, Krym nabierał wielkiego znaczenia strategicznego, zwłaszcza w kontekście rywalizacji z Turcją ${ }^{60}$. W praktyce na półwyspie ścierały się wpływy trzech znaczących osób, które w latach wojny mogły nieraz decydować o konkretnych działaniach,

56 Por. B. S. Švarc, Evrei v sovietskom sojuze s načala vtoroj mirovoj vojny (1939-1965), New York 1966; Nora Levin, The Jews in the Soviet Union. Paradox of a Survival, Vol. 1-2, New York 1966; J. S. Chonigsman, Katastrofa evrejstva zapadnoj Ukrainy. Evrei vostočnoj Galicii, zapadnoj Volyni, Bukoviny i Zakarpat'â v 1939-1945 gg., Lviv 1998; Katrin Boeckh, Jüdisches Leben in der Ukraine nach dem Zweiten Weltkrieg, „Vierteljahrshefte für Zeitgeschichte”, R. 53 (2005), H. 3, s. 421-448.

57 Die Schoah von Babij Jar - Massaker deutscher Sonderkommandos an der jüdischen Bevölkerung von Kiew 1941 fünfzig Jahre danach zum Gedenken, hrsg. von Erhard Roy Wiehn, Konstanz 1991.

58 Najnowsze badania podsumowuje Erich C. Steinhart, The Holocaust and the Germanization of Ukraine, Cambridge 2015.

59 Por. Gerald Reitlinger, The House Built on Sand. The Conflicts of German Policy in Russia. 1939-1945, New York 1960, s. 185-187; T. P. Mulligan, The Politics of Illusion and Empire. German Occupation Policy in the Soviet Union. 1942-1943, New York 1988, s. 130-131; Patrik von Mühlen, Zwischen Hakenkreuz und Sowjetstern. Der Nationalismus der sowjetischen Orientvölker im Zweiten Weltkrieg, Düsseldorf 1971, s. 183-187; Michel Luther, Die Krim unter deutscher Besatzung im Zweiten Weltkrieg, „Forschungen zur osteuropäischen Geschichte”, t. 3 (1956), s. 28-98; Norbert Kunz, Die Krim unter deutscher Herrschaft (1941-1944): Germanisierungsutopie und Besatzungsrealität, Stuttgart 2005; O.V. Roman'ko, Krym pod pâtoi Gitlera. Nemetskaja okkupacionnâ̂ politika v Krymu. 1941-1944, Moskva 2011.

60 Werner H. Krause, Kozacy $i$ Wehrmacht, Kraków 2006, s. 149 nn. 
prowadzących do eksterminacji znacznych grup ludności ${ }^{61}$. Operujący na tym odcinku frontu wschodniego feldmarszałek Erich von Manstein (1887-1973) opowiadał się za poszanowaniem zwyczajów krymskich Tatarów, przynajmniej podczas działań wojennych, by angażować jak najmniej oddziałów niemieckich w utrzymanie kontroli nad półwyspem. Starania jemu podległych dowódców doprowadziły do sformowania liczących ok. 15 000-20 000 ludzi oddziałów samoobrony złożonych z krymskich Tatarów, które później zmieniały swój status i formy zaangażowania militarnego.

Oprócz administracji wojskowej na Krymie działała niemiecka administracja cywilna, nadzorowana przez Ericha Kocha (1896-1986), pełniącego funkcję komisarza Rzeszy na Ukrainie (Reichskommissar für die Ukraine). Jego przedstawicielem na obszarze Krymu został Alfred Frauenfeld, fanatyczny nazista, znany z przesadnej oceny znaczenia gockiego osadnictwa na Krymie, które uważał za początek rozwoju prawdziwej kultury na półwyspie. Miała ona zostać zniszczona przez najazdy ludności mongolskiej, tatarskiej i kirgiskiej czy innych przedstawicieli azjatyckich „podludzi”, którzy przyczynili się do upadku tego regionu. Jego zainteresowanie „lokalnymi kulturami” było związane z planami germanizacji Krymu.

Trzecim, istotnym elementem składającym się na niemiecką administrację okupacyjną Krymu, były podległe Alfredowi Rosenbergowi struktury SS i policji. Jego podwładnym, podejmującym bezpośrednio decyzje na Krymie, był Otto Ohlendorf (1907-1951), dowódca Einsatzgruppe D. W jego opinii Karaimi stanowili sektę żydowską, co było równoznaczne ze skazaniem ich na śmierć. Hachan Seraja Szapszał w listopadzie 1941 r. zwrócił się do władz niemieckich z prośbą, aby Karaimów krymskich uznać, tak jak uznano Karaimów litewskich, za nie-Żydów. Ostatecznie Georg Leibbrandt z Ministerstwa Rzeszy do Spraw Okupowanych Ziem Wschodnich (Reichsministerium für die besetzten Ostgebiete) polecił w październiku 1942 r., aby tak właśnie traktować Karaimów ${ }^{62}$. Jednak liczba ofiar przypisywana podległym jednostkom Einsatzgruppe D wyniosła ok. 130000 mieszkańców Krymu i Kaukazu, w tym miejscowych Żydów, Cyganów i Krymczaków. Skutkiem jego działań były konfiskata i znisz-

61 Szerzej opis wydarzeń w pracy Alan W. Fisher, The Crimean Tatars, Stanford 1978, s. $152-157$.

62 Martin Broszat, Behandlung der jüdischen Sekte der Karaiten (Krim) im Rahmen der nationalsozialistischen Verfolgung der Juden, [w:] Gutachten des Instituts für Zeitgeschichte, Vol. 2, Stuttgart 1966, s. 42-43; H. Müller, Religionswissenschaftliche Minoritätenforschung, s. 145-155. 
czenie zbiorów krymskich bibliotek i innych obiektów kulturowych, które przypominały „przed-niemiecki” okres w historii Krymu. Przemiany etniczne na Krymie zostały jeszcze bardziej pogłębione przez sowieckie deportacje przeprowadzone zaraz po odzyskaniu kontroli nad Krymem, choć objęły one tylko nielicznych Karaimów ${ }^{63}$.

Po zakończeniu konferencji w Wannsee ${ }^{64} 20$ stycznia 1942 r. i rozpoczęciu wprowadzania w życie jej postanowień sprawa jasnego wskazania ofiar nabrała nowego znaczenia dla władz niemieckich. Kwestia rasowej przynależności Karaimów była jednym z takich problemów, które budziły wątpliwości. Dlatego w czerwcu 1942 r. przybył do Wilna niemiecki uczony, Georg Karl Kuhn (1906-1976) oraz urzędnik z Komisariatu Rzeszy dla Ziem Wschodnich, Fritz Steiniger, który pełnił obowiązki Rassenpolitischer Referent der Abteilung Politik, by przeprowadzić własne badania. Być może z ich pobytem wiąże się przygotowanie kilku opracowań w języku niemieckim o pochodzeniu Karaimów. Steiniger opublikował w późniejszych latach artykuły o Karaimach i Tatarach litewskich ${ }^{65}$.

Wspomniany już Georg Leibbrandt wydał 12 czerwca 1943 r. instrukcję (Schnellbrief) skierowaną do przedstawicieli niemieckiej administracji na terenach okupowanych na Wschodzie, w której stwierdzil, że „Nach den hier vorliegenden Feststellungen sind die Karaimen türk-tatarischer Herkunft (...) Eine Gleichstellung der Karaimen mit den Juden kommt daher nicht in Betracht (...)”. Byli jednak Karaimi rasowo „skażeni”, dlatego „Vermischungen von Deutschen mit Karaimen sind infolgedessen aus rassischen Gründen abzulehnen"66.

W sierpniu 1943 r. wojska niemiecki poniosły wielką klęskę w bitwie pod Kurskiem, po której armia radziecka przeszła do kontrofensywy zakończonej wyzwoleniem w 1944 r. ziem zamieszkały przez Karaimów.

W kontekście tych wydarzeń niezwykle dwuznaczne wydają się twierdzenia powtarzane od lat przez niektórych badaczy, jakoby ochotnicy karaimscy w liczbie ok. 500-600 mieli służyć w oddziałach Waffen-SS lub Wehrmachcie. Tego rodzaju opinie pojawiają się w pracach naukowych, popularnonaukowych czy prasowych. Kwestia funkcjonowania nie-niemieckich (w tym muzułmańskich

63 Aleksandr M. Nekrich, The Punished People. The Deportation and Fate of Soviet Minorities at the End of the Second World War, New York 1978, s. 13-35.

64 Mark Roseman, The Wannsee Conference and the Final Solution. A Reconsideration, New York 2003.

65 Fritz Steiniger, Bilder von Karaimen und Tataren im Ostland, „Natur und Volk”, R. 74/1-2 (1944), s. 39-48, R. 74/3-4 (1944), s. 78-84.

66 H. Müller, Religionswissenschaftliche Minoritätenforschung, s. 156-157. 
czy tatarskich) oddziałów wojskowych pod niemieckim dowództwem w strukturach Wehrmachtu oraz Waffen-SS ma swoją bogatą literaturę ${ }^{67}$. Wydaje się jednak, że autorzy sugerujący udział w nich Karaimów, mylili Arbeitsdienst (obowiązek pracy na rzecz Rzeszy) ze służbą w oddziałach wojskowych. Niemcy zmieniali nieraz swoje ideologicznie motywowane podejście do określonych grup etnicznych (np. Kozaków, Rosjan), tworząc jednostki wojskowe z nich złożone, ale nie było w nich miejsca dla Karaimów. Sugestie o związkach Karaimów z Tatarami, wspólnej służbie wojskowej na rzecz Niemiec, licznych małżeństwa mieszanych są nieporozumieniem ${ }^{68}$. Jedyną opinią, z którą można się zgodzić, to pokrewieństwo językowe karaimsko-tatarskie na Krymie.

Bez wątpienia punktem wyjściowym do monograficznego opracowania dziejów Karaimów w tragicznych latach drugiej wojny światowej jest zebranie źródeł, które później należy krytycznie przeanalizować.

67 Na próżno szukać wzmianki o Karaimach w mundurach niemieckich w ostatnio wydanych pracach. Por. Sergej Čuev, Proklâtyje soldaty, Moskva 2004; Jarosław W. Gdański, Zapomniani żotnierze Hitlera, Warszawa 2005; Klaus-Michael Mallmann, Martin Cüppers, Półksiężyc i swastyka. III Rzesza a świat arabski, Warszawa 2009; W. H. Krause, Kozacy i Wehrmacht, Kraków 2006; Samuel J. Newland, Kozacy $w$ Wehrmachcie 1941-1945, Warszawa 2010; Jürgen Thorwald, Iluzja. Żotnierze radzieccy $w$ armii Hitlera, Warszawa 2010; Chris Bishop, Zagraniczne formacje SS. Zagraniczni ochotnicy $w$ Waffen SS $w$ latach 1940-1945, Warszawa 2006; Peter Gosztony, Hitlers fremde Heere. Das Schicksal der nichtdeutschen Armeen im Ostfeldzug, Düsseldorf, 1976; David Motadel, Islam and Nazi Germanys War, Cambridge 2014; Hans Werner Neulen, An deutscher Seite: internationale Freiwillige von Wehrmacht und Waffen-SS, München 1985; Christopher Hale, Kaci Hitlera. Brudny sekret Europy, Kraków 2012; Rolf-Dieter Müller, An der Seite der Wehrmacht. Hitlers ausländische Helfer beim "Kreuzzug gegen den Bolschewismus". 1941-1945, Berlin 2007 (angielski przekład: The Unknown Eastern Front: The Wehrmacht and Hitler's Foreign Soldiers, New York 2012; II wyd., 2014; polski przekład: Wspólnicy Hitlera. Formacje sojusznicze Wehrmachtu na froncie wschodnim, Warszawa 2014, s. 294-295, gdzie mowa o „ludności turecko-tatarskiej” na Krymie, choć nazwa Karaimi nie została wymieniona).

68 Tezę o rzekomym udziale Karaimów w oddziałach Wehrmachtu oraz Waffen-SS powtórzył w artykule prasowym David B. Green, This Day in Jewish History. Nazis declare: Karaites are not racially Jewish, „Haaretz”, wydanie z 5 stycznia 2015 (http:// www.haaretz.com/news/features/this-day-in-jewish-history/.premium-1.635335 dostęp: 06.01.2015). 


\section{Aneks}

Dokumenty są obecnie przechowywane w zbiorze F 143 (Kolekcja Seraja Szapszała) w Bibliotece im. Wróblewskich Litewskiej Akademii Nauk (Lietuvos Mokslų Akademijos Vrublevskių Biblioteka) w Wilnie. Jedynie wykaz członków gminy karaimskiej w Wilnie w wieku od 20 do 50 lat został spisany 20 listopada 1942 r. odręcznie, wszystkie pozostałe dokumenty zostały sporządzone $\mathrm{w}$ formie maszynopisu.

\section{[5.10.1934]}

LMAVB, F 143-1038, f. 11r

Warszawa, Aleje Jerozolimskie 75-4, dnia 5 października 1934 r.

Czcigodny Kapłanie,

Od dłuższego czasu interesują mnie kanony i rytuał wyznania karaimskiego. Jakie formalności wymagane są dla zmiany wyznania mojżeszowego na karaimskie ? O łaskawe udzielenie wyczerpujących informacji uprzejmie prosi sługa uniżony

Dawid Gold.

\section{[24.04.1936]}

LMAVB F 143-981, fol. 98r

Wiktor Serog, urzędnik prywatny,

Bielsko, ul Mickiewicza 35 /I. p.

Bielsko, dnia 24 kwietnia, 1936.

P.T.

Zarząd Karaimskiej Gminy Wyznaniowej

Wilno

Brat mój architekt Józef Serog w Cieszynie miał sposobność częściowo zapoznać się z przepisami Wyznania Karaimskiego i ma zamiar wraz ze mną przejść na to Wyznanie.

Niniejszem pozwalam sobie zwrócić się do P.T. Zarządu z uprzejmą prośbą o łask[awe] udzielenie mi szczegółowych. informacji, czy i przy dopełnieniu jakich formalności możliwem byłoby prze jecie na Karaimskie Wyznanie.

Na łask[awą] odpowiedź załączam znaczek pocztowy i kreślę się

Serog Wiktor 


\section{[11.12.1936]}

LMAVB, F 143-1038, f. 17r [tekst po polsku i po niemiecku]

Hachan Karaimów w Polsce

Wilno, 11 grudnia 1936

\section{Świadectwo}

Wobec powstałych nadużyć wydawanie się za Karaimów osób do tego wyznania i narodowości (tiurkskiej) nienależących, niniejszym upoważniam p. Michała-Musy Kowszanły, zamieszkałego w Berlinie, do oficjalnego reprezentowania Karaimów na terenie Rzeczypospolitej Niemieckiej i stwierdzania ich niewątpliwej przynależności do tego wyznania i narodowości, w razie powstania takiej potrzeby.

Hachan Karaimski w R.P.

\section{[14.10.1938]}

LMAB, F 143-1081, fol. 45r

Der Reichsminister für die kirchlichen Angelegenheiten

Berlin, den 14. Oktober 1938

Auf Ihr Schreiben vom 28. September 1938, betreffend Prüfung der rassischen Zugehörigkeit der Karaimer.

Sie wollen die von Ihnen in einem Exemplar eingereichte Denkschrift in zwei weiteren Stücken hier einreichen. Die Angelegenheit wird unter Umständen die Einholung einer eingehenden gutachtlichen Äußerung des russisch-orthodoxen Bischofs Seraphim sowie des Professors Unruh-Karlsruhe erforderlich machen. Ich bitte um gefällige Mitteilung, ob Sie bereit sind, die durch die Einholung dieser Gutachten entstehenden Kosten zu übernehmen. Ich bemerke ferner, daß auf diese Weise zunächst nur die allgemeine rassische Einordnung der Karaimer geprüft werden kann, nicht auch die rassische Zugehörigkeit bestimmter einzelner Personen. Dazu bedarf es der Beibringung der jeweils erforderlichen weiteren Unterlagen. Im übrigen habe ich mich mit dem Herrn Reichsminister des Innern (Reichsstelle für Sippenforschung) in Verbindung gesetzt.

In Vertretung

gez. Dr. Muhs

in den

Herrn Wirklichen Staatsrat

S. von Duvan

Tauentzienstr. 7a

bei Heise 


\section{[14.10.1938]}

LMAVB, F 143-1038, fol. 5r

Wilno, 14 października 1938

Do Wydziału Konsularnego Ambasady Niemieckiej w Warszawie przez starostwo grodzkie wileńskie

W uprzejmej odpowiedzi na pismo Wydziału Konsularnego Ambasady z dn. 28 września r.b., mam zaszczyt podać do wiadomości, że Karaimi zamieszkali w Polsce, jako narodowość należą do plemion tureckich, mówią narzeczem tureckim i są uznanej przez Państwo Polskiej religii karaimskiej.

Co się tyczy omawionego w piśmie Wydziału Konsularnego p. Maksa Krafczuka, będącego jakoby pochodzenia karaimskiego (vel karainskiego) i wyznania staromojższowego, to już samo ostatnie określenie wskazuje, kim on jest z wyznania religijnego; nie może również wymieniony p. Krafczuk być pochodzenia turecko-karaimskiego, gdyż takiego imienia i nazwiska Karaimi nie mogą posiadać. Prawdopodobnie, petent jest jednym z wielu będących w Niemczech lub stamtąd przybyłych, którzy szukają wyjścia z niearyjskiego swego pochodzenia na drodze fałszu.

/S. Szapszał/

\section{[5.01.1939]}

LMAVB, F 143-1038, f. 38r ${ }^{69}$

Der Leiter der Reichstelle für Sippenforschung

Berlin, 5 Januar 1939

Herrn

S. von Douvan,

Berlin S 50

Tauentzienstr. $7 \mathrm{a}$

Auf Ihre Eingaben vom 5. September und 10. Oktober 1938 an den Herrn Reichsminister des Innern wird Ihnen folgendes mitgeteilt.

69 Dnia 7 listopada 1941 r. na prośbę Ignacego Izaaka Zajączkowskiego, zam. w Wilnie, na podstawie poświadczonego odpisu z 24 marca 1939, została sporządzona notarialna kopia tego dokumentu, z opisem czynności notarialnej po polsku i po litewsku; por. LMAVB, F 143-1038, f. 92r. 
Die Sekte der Karaimen ist nicht als jüdische Religionsgemeinschaft im Sinne des $§ 2$ Absatz 2 der Ersten Verordnung zum Reichsbürgergesetz anzusehen. Die Feststellung, dass die Karaimen in ihrer Gesamtheit artverwandten Blutes sind, kann jedoch nicht erfolgen, denn die rassische Einordnung einer Person lässt sich nicht ohne weiteres nach ihrer Zugehörigkeit zu einem bestimmten Volke, sondern immer nur nach ihren persönlichen Abstammungsverhältnissen und rassebiologischen Merkmalen vornehmen.

Die eingereichten Unterlagen folgen anbei zurück.

Im Auftrage

/-I

\section{[11.02.1939]}

LMAVB, F 143-1038, f. 15r

Port-au-Prince, Haiti, 11 lutego 1939

Przewielebny Arcypasterzu,

Kierowany silnym wewnętrznym postanowieniem i głębokim przekonaniem z pokorą proszę o przyjęcie mnie w poczet wiernych wyznawców wiary karaimskiej.

Urodzony 11 lutego 1896 r. w Łodzi ojca Anczela i matki Rywki z Dorenbuszów, ostatnio zamieszkały w Warszawie, od pół roku w Rzeczypospolitej Haiti, dotąd wyznania mojżeszowego, aptekarz, obywatel polski. Żona moja Alicja z ojca Izydora Leszczyńskiego, matki Jenny z Cohnów, urodzona 25.1.1904, syn mój Jerzy, urodzony 5.6.1930 w Będzinie i córka Urszula, urodzona 14.9.1932 w Będzinie.

Wszelkie opłaty i należności prześlę niezwłocznie lub też zdeponuję w jakimkolwiek banku, względnie prześlę je z mego konta PKO w Warszawie.

I łaskawe przeprowadzenie wszelkich formalności, przesłanie katechizmu, książki do nabożeństwa w języku polskim lub francuskim oraz 4 metryk uprzejmie prosi pokorny sługa,

Dawid Gold 


\section{[7.08.1939]}

LMAVB, F 143-1038, f. 14r

Port-au-Prince, Haiti, 7 Aout 1939

[na papierze firmowym Pharmacie Centrale. Laboratoire de Chimie et de diagnostic medical]

Przewielebny Pasterzu,

Niniejszym zgłaszam przystąpienie moje oraz rodziny, żony i dwojga dzieci do Gminy Wyznaniowej Karaimskiej. Personalia nasze podane w liście z dn. 11.2. r.b. są następujące:

Dawid Gold, urodz. 11.2.1896 w Łodzi, syn Anczela i Rywki z Dorenbuszów, aptekarz, ostatnio zamieszkały w Warszawie, od grudnia 1938 zaś w Haiti, dotąd wyznania mojżeszowego, obywatel polski.

Alicja Gold, urodz. 25.1.1904 w Kcyni, córka Izydora i Żenny z Cohnów Leszczyńskich, żona moja od roku 192814 listopada.

Jerzy Gold, syn mój, urodz. 5.6.1930 w Będzinie.

Urszula Gold, córka moja, urodz. 14.9.1932 w Będzinie.

Uprzejmie proszę o urzędowe potwierdzenie niniejszego zgłoszenia.

Wraz z niniejszym przesyłam oficjalne zawiadomienie do Urzędu Stanu Cywilnego w Warszawie o zmianie.

Racz przyjąć, Czcigodny Pasterzu, wyrazy głębokiej czci i przywiązania.

Dawid Gold

\section{[16.09.1941]}

LMAVB F 143-1053, fol. 4r-4v

Der Gebietskommissar in Schaulen

Schaulen, am 16 Sept. 1941. Schr/Hp.

Am sämtliche Kreishauptleute und Bürgermeister im Gebiet Schaulen Betr.: Judenangelegenheiten

Zur Ergänzung der von uns herausgegebenen Richtlinien über die Behandlung der Juden teilen wir folgendes mit.

Nach einer Entscheidung der Reichsstelle für Sippenforschung vom 5.1.1939 ist die Sekte der Karaimen nicht als jüdische Religionsgemeinschaft im Sinne 
des §2 Absatz 2 der Ersten Verordnung zum Reichbürgergesetz anzusehen. Die Karaimen sind Türken aus der Zeit vor der Beimischung mit Arabern. Sie sind von Witold um das Jahr 1388 aus der Krim in Grossfürstentum Litauen angesiedelt worden. Ihre Zentrale ist Troki. wo sie zu rund 300 Personen in einem besonderen Teil von Troki, der Karaimenstrasse, wohnen. 300 leben in der Stadt Wilna, einige in Ponewesch, einige vereinzelte in als deren Städten. Im ganzen gibt es in Litauen 6-700 Karaimen, in der Krim 15.000 und ebenso viel in der Türkei und Egypten (7-8000 in Kairo). Die Karaimen sprechen eine alt-türkische Sprache, die auch an der Universität Berlin gelehrt wird, und werden sowohl von der Türken wie von den Sowjetrussen zu den türkischen Völkern und nicht zu den Juden gezählt.

Ihre Religion ist sehr gemischt. Die Grundlage ist hebräisch mit der besonderen Richtung der Sadduzäer ohne Talmud; hinzu kommen christliche und mohamedanische Elemente. Christus und Mohamed werden als Propheten anerkannt. Wie bei allen Orientalen, auch den Türken, herrscht auch bei den Karaimen die Sitte der Beschneidung.

Die Leitung des Volkes der Karaimen durch sein geistliches Oberhaupt erfolgt von Troki aus (auch für die Türkei und Egypten), so dass die Behandlung der hiesigen Karaimen auch bezugl. der in der Krim und in übrigen Orient wohnenden von Bedeutung ist.

Nach dem Ausseren der in Troki gesehenen zu urteilen, machen die Karaimen einen überwiegend: tatarisch vorder-asiatischen Eindruck; dunkel, mit offenen brauen Augen, hervortretenden Backenknochen, zum Teil armenoiden Hochschädel und leicht vorder-asiatischen Nasen. Weder ihre Bewegungen noch ihr ganzes Auftreten macht einen jüdischen Eindruck. Die Karaimen betreiben Acker- und besonders Gartenbau. Vielfach sind die Offiziere gewesen und haben in Russland bei der Garde gedient. In früheren Zeiten bildeten sie zum Teil die Leibgarde der litauischen Grossfürsten und polnischen Könige worüber Unterlagen vorliegen. Die in Deutschland lebenden 18 Karaimen sollen auch zum grössten Teil ehemalige Wrangel-offiziere (Antibolschewisten) sein. In dem unscheinbaren Haus von Firkowicz befand sich ein gut gearbeiteter Dokumentenschrank (Geschenk des polnischen Staats- Präsidenten Moszicki), in dem die Originale der Privilegien der polnisch Könige aufbewahrt werden (vom Jahre 1595 etwa anfangend). Es handelt sich unter anderem; um Originalurkunden von Sigismund dem Ersten, Sigismund August, Stephan Batory und Johann Sobiersky [sic!].

Obwohl in Troki ausser den Karaimen eine recht zahlreiche jüdische Bevölkerung ansässig war, soll seit 530 Jahren, dem Ansiedlungsdatum der Karaimen, kein Fall einer Vermischung mit Juden vorgekommen sein. Im Gegenteil, die Karaimen halten sich den Juden fern und lehnen sie ähnlich. der örtlichen arischen Bevölkerung an.

Kurz vor dem Einmarsch der Deutschen sollten die gesamten Karaimen von den Bolschewisten verschleppte werden. 
unter den oben geschilderten umständen dürfte es sich empfehlen die Karaimen nicht den Juden gleichzustellen.

Dieses Rundschreiben wollen Sie auch den Bevollmächtigten für jüdische Allgelegenheiten zur Kenntnis bringen.

Stabsleiter (Unterschrift)

Für die Richtigkeit der Abschrift

Sekretär des Kreischefsamtes in Biržai (Unterschrift)

\section{[1941-1942]}

LMAB, F 143-846, fol. 3r-4v

\section{Übersetzung}

Die Abstimmung der Krimer und Litauischen Karaimen

Die Lehre der Karaimen, welche im VIII Jahrhundert als ein Protest gegen den, durch sie nicht anerkannten Talmud in Mesopotanien entstand, begann sich schnell zuerst zwischen den Juden auszubreiten, später aber, wie andere Glaube drang sie in verschiedene ethnische Kreise ein.

Historisch ist es bekannt, dass ein Teil des türkischen Volkes - der Chasaren, in der Epoche seiner höchsten Macht und Aufblühens, am Ende des VIII. Jahrhunderts und Anfang IX. Jahr. diese Lehre annahm. Der Chagan selbst, seine Hofangehörigen und die ganze Regierungsklasse hatte sich zum Karaimischen Glauben bekannt, jedoch zwischen dem Volke war auch Islam und das Christentum verbreitet ${ }^{1}$.

Am Ende des XI. Jahrhunderts ist das Chasarenreich zerfallen und das zahlreiche Chasarische Volk vermischte sich allmählich mit den sie umgebenden Völkern, wobei sich die Christen mit ihren Erobern den Russen und den Muselmanen mit der Petschenegenmasse und später den Polowtzen vermischten.

Wo blieb aber der Teil der Chasaren, der sich zur Lehre des Alten Testaments bekannte? Die Gelehrten-Orientalisten, die sich speziell mit dem historischen Schicksal der uralten Bevölkerung Südrusslands beschäftigten, sind zu der Überzeugung gekommen, dass die jetzigen, das Alte Testament ohne Talmud bekennenden und auf dem alttürkischen Idiom, sprechenden Karaimen, zweifellos Nachkommen dieser Chasaren sind.

\footnotetext{
1 In der letzen Zeit haben darüber die muselmanischen Gelehrten: 1. Ajaś-Ishaki, „Idel-Ural”, Paris 1933, S. 9-10, 2. Dr. Abdullah Zihni Soysal, „Z dziejów Krymu”, Warszawa 1938, S. 12v13, geschrieben. [Przypis oryginalny].
} 
Die Karaimen selbst waren ihren türkischen Abstammung immer bewusst und haben daher noch in der Vorzeit die heilige Bibel und die Gebetsbücher in die türkische Sprache, ihre Muttersprache, übersetzt und benutzen dieselben beim Gottesdienst auch in der heutigen Zeit.

Die Juden, und vielleicht nicht nur die Juden selbst, sehen alle monotheistischen Religionen nicht mehr und nicht weniger als jüdische Sekten an. So ist auch die Lehre der Karaimen beinahe in allen enzyklopädischen Wörterbüchern als solche bekannt, wobei die Autoren der Artikel über Karaimen meistens Juden sind.

Beim Studium eines jeden Volkes muss man die Rassenabstammung von dem Glauben, zu dem sich das Volk bekennt, streng unterscheiden. Anderfalls wäre es doch ein Unsinn, wenn man z.B. behaupten würde, dass die Europavölker, Abyssinier und ein Teil der Chinesen, Japaner und Neger, welche das Christentum annahmen, also Völker verschiedener Rassen, Stämme und Sprachen, ein Volk seien, deswegen nur, dass sie an Christus, und an seine Lehre glauben.

Ebenfalls darf man auch nicht die Karaimen nur deswegen, dass sie sich zum Alten Testament bekennen und den Sonnabend feiern als Juden ansehen. Das Alte Testament ist doch von allen Christen anerkannt, und Sonnabend feiern auch die Christen-Adventisten und manche orthodoxen Pfarrgemeinde in Konstantinopol.

Woran sind dann, außer Religion, verschiedene Völker zu unterscheiden? Zweifellos, dass in erster Reihe an ihrem Typus, Sprache, Lebensart, Gebräuchen und an allen ihren Volkseigenschaften Folklore. [3v]

Die Gelehrten Orientalisten, sehen die Karaimen der Krim nicht anders an, als ein Volk unbedingt türkischer Abstammung. So z.B. Prof. Smirnoff, ein Historiker der Krim, der die bekannte Festung dieser Halbinsel, Dschuft-Kale bespricht, äußerte sich unter anderem folgendennassen: „Die Karaimen sind ein Rest des ehemals in der Krim herrschenden Chasarenvolkes, welches durch eine andere wenn auch verwandte Völkerschaft verdrängt wurde und haben sich in der uralten Festung von Dschuft-Kale niedergelassen”2.

Wenn wir die vielen anderen Historiker und Philologen-Orientalisten welche auf grund historischer und sprachlicher Beweise, schon längst die türkische Abstammung der Karaimen festgestellt haben, beiseite lassen, so sehen wir, dass dafür auch viele andere Beweise vorhanden sind.

Professor der Kunstgeschichte an der Wilnaer Universität, M. Morelowski stellt auf Grund einer strengen Forschung und Studium der geometrischen Ornamentik auf den Handtüchern und anderen Handarbeiten. Geweben und Erzeugnissen der karaimischen Frauen aus der Krim, durch ihren Vergleich

2 W. Smirnoff, „Tatarskie-chansko jarłyki” (Tatarisch-chanischen Vorrechte) in Nr. 54 der „Isviestija Tavritscheskoj utschenoj archivnoj komisji”, Simferopol 1917, S. 3-4. Sonderabdruck. [Przypis oryginalny]. 
mit den Erzeugnissen anderer schon in dieser Beziehung erforschten Völkerschaften, gleichfalls die türkische Abstammung der Karaimen fest ${ }^{3}$.

Die Texte der karaimischen Märchen und ihrer Heldenlieder, wie auch die ganze karaimische Folklore bestätigt dasselbe ${ }^{4}$.

Durch anthropologische Ausmessungen ist die Verwandtschaft mit den anderen Türken schon längst festgestellt worden und es besteht darüber eine ganze Literatur. Um aus dem Rahmen dieser Übersicht, durch Hinweise auf die früheren Erforschungen auf diesem Gebiet, nicht herauszutreten, werde ich nur auf die Arbeiten letzter Zeit hinweisen.

Professor der Wilnaer Universität - Michel Reicher publizierte nach Durchführung der anthropologischen Ausmessungen und der Blutforschung bei den Karaimen in Wilna und Troki (deren Vorfahren durch den litauischen Grossfürsten Witold im XIV. Jahrhundert als Kriegsgefangene aus der Krim mitgeführt waren) die Ergebnisse seiner Arbeit im Jahre 1932 in französischer Sprache, in der in Prag erscheinenden tschechische Zeitschrift „Anthropologie”. Der Autor dieser Arbeit bemerkt unter anderem: „Quant aux peuples turco-tatars une plus grande ressemblance se montre entre eux et les Caraimes polonais, qu'entre ces derniers et les Juifs. Ici les Tchouwaches semblent se rapprocher le plus des Caraimes polonais aussi bien au point de vue de la frequence du groupe B, que pour le plus petit poucentage du groupe 0 " . [4r]

Danach begann sich der Vorstand, des „Comitato Italiano per le Studio dei Problemi della Popolazione” Prof. Corrado Gini für die Karaimen zu interessieren und ist im Jahre 1934 in Polen an der Spitze einer ganzen Expedition angekommen. Er hatte bei den Karaimen nicht nur in den allen vier Gemeinschaften Polens Forschungen durchgeführt (im Gegensatz zu dem Prof. Reicher, der diese nur in den erwähnten 2 Gemeinschaften durchführte), sondern hat sich auch nach Litauen begeben, um die dortigen Karaimen zu unter suchen.

Die Ergebnisse seiner Erforschungen hatte Prof. Gini in der Zeitschrift „Genus” (dem Organ des Komites, dessen Vorstand er ist) unter dem Titel „I Caraimi di Polonia e di Lituania” veröffentlicht. Dieser umfangreiche Artikel (58 Seiten) macht die Hälfte der vielseitigen Arbeit dieses Gelehnten aus. Auf Seite 58. des Sonderabdrucks steht es: „Essi sarabero, da questo punto di vista, molto simili ai Csiuvasci”. Wiederum wird auf nahe Rassenverwandtschaft der Karaimen

3 Siehe seinen Artikel in „Myśl Karaimska”, H. X, 1934: „Tkaniny ludowe karaimskie, a sprawa pochodzenia Karaimów krymskich i polskich”. [Przypis oryginalny].

4 Türk Yili, Istambul 1928, Artikel: „Kirim Karai Türkleri”. Sonderabdruck, S. 34-35. [Przypis oryginalny].

5 „Anthropologie”, 1932, S. 265 - „Sur les groupes sanguiens des Caraimes de Troki et de Wilna”, Par le Prof. Dr. Michael Reicher. [Przypis oryginalny].

6 Siehe Zeitschrift „Genus”, Roma 1936, S. 56. [Przypis oryginalny]. 
an Tschuwaschen hingewiesen, d.h. anders gesagt, an ein Volk, das mit Juden garnichts gemeinsames hat.

Hierbei kann man auch etwas über das in der letzten Zeit erschienene Buch des A. Baschmakoff „Cinquante siècles d'evolution ethnique autour de la Mer Noire" ${ }^{7}$ erwähnen, worin sich unter anderem auch ein umfangreiches Material über die Karaimen befindet. Ein Resumé über diese Arbeit war durch W. Tatarinoff in der in Riga herausgegebenen Zeitung „Segodnia”, wie auch in dem Pariser „Vosroschdenie”“ veröffentlicht. In dieser Arbeit äußert sich der Autor, dass die Karaimen, samt den Tataren der Südufer Krims, die Aborigenen der Halbinsel vorstellen, indem sie die Nachkommen der Krimmerer seien, wobei die bei den Völker sich türkisiert haben. Bei den Karaimen geschah es unter dem Einfluss der Chasaren, indem sie amt den letzten, ihre gegenwärtige Religion annahmen und ihre türkische Sprache übernahmen.

In anthropologischer Hinsicht seien die Karaimen, gleich wie die erwähnten Tataren, den Tscherkessen ähnlich und ihre Familiennamen zeigen auf den Zusammenhang mit dem Kaukasus hin.

Nachdem wir hier alles was uns die Gelehrten letzter Jahre gaben aufgezählt haben, müssen wir noch darauf hinweisen, dass die Sprache der Polen bewohnenden Karaimen durch Prof. T. Kowalski, den Mitglied der ehem. Polnischen Akademie der Wissenschaften gründlich erforscht war, und derselbe eine umfangreiche Arbeit in dieser Frage herausgegeben hat. Nach dem Erscheinen dieses Buches ist ein Interesse für die Sprache der Karaimen entstanden, und sie wurde auch an der Berliner Universität, an dem Katheder türkischer Sprachen durch Professor Dr. W. Bang-Kaup vorgetragen.

Aus allem obenerwähnte; ist es zu ersehen, dass nach ihrem Typus, Blut und Sprache, die Krimer-polnisch-litauischen Karaimen als ein Volk türkischen Stammes vorkommen, als welches sie sich selbst ansehen und daher erstand sind, wenn man sie manchmal mit Juden wechselt. Wir müssen hier auch darauf hinweisen, dass nicht nur die Karaimen selbst, sondern auch ihre nähesten Verwandten, die jetzigen Beherrscher Kleinasiens und eines Teiles des europäischen Kontinents d.h. der Türkischen Republik, ihnen niemals die Verwandtschaft durch Blut und Sprache streitig gemacht haben.

Es genügt in die Arbeiten der. Professoren der Istambuler Universität, Dr. Fuad Koprülü-Sade, Dr. M. Schemsedin, Dr. Nedschib-Asim u. A. [4v] anzusehen, um sich darüber völlig zu überzeugen. Im Jahre 1932 wurde durch Gusain Namil das Buch „Turk Dunyasi” - Die türkische Welt, herausgegeben, das ein Lehrbuch für türkische mittlere Schulen darstellt und kurze Auskünfte über alle türkischen Völkerschaften enthält. Auf den Seiten 179-180 dieses Buches befindet sich „Karaim Turkleri”, d.h. „Türken-Karaimen”, worin hingewiesen, wird, dass im Süden Russlands und in Pulen, zur Zeit 15.000 dieses

Paris 1937. [Przypis oryginalny]. 
Volkes - Türken reines Blutes wohnen, die sich von nichts anderen als der Religion von den übrigen Türken unterscheiden.

Als die Türken nach der Initiative ihres Präsidenten Kemal Atatürk, nach Annahme der lateinischen Schrift, zur Bereinigung ihrer Sprache von der unglaublich grossen Ansammlung ausländischer Wörter - arabischer und persischer - antraten, fingen sie an, um die letzten zu ersetzen, die rein türkischen Wörter bei.den verwandten Völkerschaften zu suchen. Die Karaimen können stolz sein, dass sie ihnen 330 alttürkische Wörter nennen konnten.

Es wird hierbei hingewiesen, dass in dem, im J. 1937 im Istambul im Palast Dolma-Bagtsche am Bosporus eingerichteten Türkischen Staatsmuseum an einer Ward eine riesige Karte dargestellt ist, auf der die Punkte der Verbreitung türkischer Völkerschaften und Sprachen durch Ziffern aufgetragen sind. Auf dieser Karte sind mit Nr. 3. die litauischen und politischen Karaimen bezeichnet.

Zum Schluss bleibt es uns darauf hinzuweisen, dass man unter den Kosaken des jemaligen Saporoger Kosakenlandes auch Karaimen nach dem Glauben antreffen konnte, deren Nachkommen noch bis zur heutigen Zeit in der Kubaner Gegend, nicht weit von Ekaterinodar, in dem Kosakendorf Michajlowskaja, an der Eisenbahnstation Kurgannaja sich bewahrt haben. Wie in der russischen Geschichtkunde von Solowioff und Kostamaroff so auch in der polnischen von Ks. Simon Okolski hat sich der Name eines berühmten Obersten des SaporogerKosaken-Heeres, des Perejaslawler Obersten Eliasch Karaimovitsch, der einige Zeit Hettmanns Pflichten ausführte, erhalten.

Zweifellos ist es, dass dieser E. Karaimowitsch im XVII. Jahrhundert und die jetzigen Nachkommen der Saporoger Kosaken in Kuban, sowie auch hunderte der Offiziere verschiedener Waffen der ehem. kaiserlich-russischen Armee, indem sie karaimischer Religion waren und aus der Krim stammten, niemals erlaubt hätten sie als Juden anzusehen oder zu nennen. Es ist doch bekannt, dass in der ehemaligen russischen Armee, sogar die Nachkommen getaufter Juden bis zum dritten Grade nicht zu Offizieren befördert worden konnten.

Endlich, was die altbiblischen Namen bei den Karaimen, wie Abraham, David, u.a. anbetrifft, so schämen sich deren die Karaimen nicht und verdecken sie nicht durch ähnlich klingende christliche Namen, damit man sie nicht in Verdacht hätte jüdischer Abstammung zu sein. Neben diesen Namen begegnet man bei den Karaimen auch rein nationale türkische Namen wie: Babakai, Babadschan, Tochtamysch, Akbike usw. Obgleich die Namen Alexander, Nikolaus, Andreas griechischen Ursprung sind und Konstantin, Viktor - lateinischen, so kann man doch die Russen, die diese Namen tragen nicht als Griechen oder Römer, und alle Christen, die altbiblische, jüdische Namen haben, wie z.B. Josef, Michael, Gabriel, Jeremij, Eliasar, Anna, Elisabeth u.a. nicht als Juden ansehen.

Hachan der Karaimen

Prof: Hadschy Seraia Schapschal 


\section{[23.04.1942]}

LMAVB, F. 143-845, fol. 1r-2v

Die Stellung der karaimischen Konfession unter anderen monotheistischen Bekenntnissen

Der von einer tiefer Hochachtung für die deutsche Wissenschaft durchdrungene und selbst in ihr erzogene französische Gelehrte Ernst Renan charakterisierte bei einer Gelegenheit folgendermaßen sein eigenes Volk: „Die Franzosen sind Römer durch ihre Sprache, Griechen durch ihre Zivilisation und Juden durch ihre Religion"1.

Wenn wir auf diese Weise an die eine oder die andere der existierenden monotheistischen Religionen, und an jede von ihnen besonders, herantreten, so unterliegt es keinem Zweifel, dass alle christlichen Bekenntnisse und alle Abarten islamischer Bekenntnisse nichts anderes sind, als jüdische religiöse Sekten, und zwar insofern, als sie in Anerkennung der göttlichen Herkunft des Alten Testaments, dieses ihren Lehren zugrundelegen. Es gibt keinen Grund, dass in dieser Beziehung für den karaimischen Glauben eine Ausnahme gemacht werde, der das Alte Testament als Grundlage seiner Lehre anerkennt, der aber das spezifische jüdische Recht - den Talmud - verwirft.

Warum treten die Juden selbst auf zweierlei Weise an die Frage der karaimischen Religion heran? In Artikeln und in Werken, die in europäischen Sprachen erschienen sind (vornehmlich in enzyklopädischen Wörterbüchern u.dgl.) behaupten sie, dass der Karaismus nichts anderes sei, als die ein wenig abgeänderte Glaubenslehre der Juden, die am Anfang des VIII Jahrhunderts in Babylon von Anan-Ibn-Daud mehr als politische Opposition gegen das derzeitige Judentum im Zusammenhang mit dem um die Gewalt des „Exilarchen” entbrannten Kampf begründet worden ist.

In Werken jedoch, die in jüdischer Sprache geschrieben und ausschließlich für Juden bestimmt sind, behaupten sie bis in die letzte Zeit hinein hartnäckig, der Karaismus habe mit der jüdischen Religion nichts gemeinsames, wobei ihn die einen dem Christentum, die anderen dem Islam nähebringen.

Weder die einen noch die anderen verschonen die Karaimen nicht mit Fluchworten und verlangen von ihren gläubige Mitbrüdern, den Talmudisten, die entgültige Ausrottung der Karaimen, wobei sie sogar die Anwendung von Mord gestatten. Der Leser könnte meinen, es sei die Rede von längst vergangenen

1 Siehe seine berühmte Rede über „den Islam und die Wissenschaft”, die öffentlich in der Versammlung der französischen Wissenschaftlichen Gesellschaft am 29 März 1883 im grossen Amphitheater der Sorbonne gehalten wurde. [Przypis oryginalny]. 
Zeiten, vom Mittelalter im Zeiträume religiöser Entgleisungen, in Wirklichkeit aber wird hier von Erscheinungen unserer Zeit gesprochen.

So, z.B. finden wir in dem die Geschichte der Juden im Ottomanischen Imperium behandelnden und von dem spanischen Juden M. Franco verfassten Buche folgende Nachricht: „En novembre 1866, le rabbin Chelomo Camhi publia une brochure, où il accumula contre les Caraites toutes les horreurs formulees contre eux par les anciens auteurs. Comme conclusion, il finit par revaler les Caraites aurang des bêtes et precha comme une oeuvre agréable à Dieu l'extermination de cette communauté” ${ }^{2}$. Weiter wird der Titel der genannten Broschüre „Melechet-Chelomo” angeführt und hinzugefügt: „il est dit dans cet écrit [1v] que les Caraites étant purement et simplementt des bêtes, non seulement il est défendu de leur enseigner la Loi, mais il est permis de les tuer”.

Wir sind der Ansicht, dass kein Bedürfnis vorliege, an. dieser Stelle alle charakteristischen Kennzeichen der karaimischen Religion darzulegen und die Dogmen des karaimischen Glaubensbekenntnisses anzuführen, indem sie gleichzeitig jüdischen Dogmen gegenübergestellt werden. Die zwischen diesen zwei Religionen, vorhandene Kluft kann nie und nirgends zugeschüttet werden. Zwischen dem Karaimentum und dem Judentum (dem Judaismus) ist eben derselbe Unterschied, wie zwischen dem Christentum und dem Judaismus. Der Karaismus und das Christentum haben mit der jüdischen Religion die Fünf Bücher und die Bücher der Propheten gemeinsam, wobei sowohl die Christen als auch die Karaimen den zweiten teil des jüdischen Glaubensbekenntnisses, und zwar den für das Judentum so wesentlichen Talmud ablehnen. Wenn dem so ist, warum identifizieren manche die karaimische Religion mit der jüdischen oder unterscheiden so wenig?

Dies kommt wahrscheinlich daher, dass die Karaimen den Samstag feiern. Laien, die sich im karaimischen Glaubensbekenntnisse wesentlichen überhaupt nicht orientieren, sehen dieses äußere Merkmal als Beweis dafür an, dass sich diese beider Konfessionen nahestehen. Doch auch Christen, insbesondere Adventisten und eine nicht große Gemeinde orthodoxer Griechen in Istambul (die Pfarrei Kuru-Tscheshme) feiern ebenso den Samstag statt des Sonntags, was sie nicht hindert, treue Anhänger der christlichen Kirche zu bleiben. Worin also besteht die karaimische Glaubenslehre?

Die Karaimen behaupten, dass der Anfang ihrer Glaubenslehre als Protest gegen den Talmud, an dessen göttliche Herkunft die Juden glauben, aus erheblich früheren Zeiten als dem VIII Jahrhundert stammt, zu welcher Zeit

2 M. Franco, „Essai sur l'histoire des Israélites de l’Empire Ottoman depuis les origines jusqu'à nos jours”, Paris 1897, S. 171. [Przypis oryginalny].

3 Ibidem, Seite 172. Siehe auch „The Karaite Literary Opponant of Saadiah Gaon”, Seite 101. [Przypis oryginalny]. 
Anan-Ibn-Daud so entschieden gegen die Talmudisten aufgetreten ist. Die Begründer des Karaismus lebten in Palästina zu Zeiten des Erdendaseins Jesu Christi, was I.G. Trotzkij, Professor an der Petersburger Geistlichen Akademie feststellt, indem er sich auf die Autorität des Moskauer Metropoliten Filaret beruft ${ }^{4}$. Die Karaimen selbst sind der Ansicht, dass ihr Glaube das Christentum in seiner ersten Form darstelle, d.h. so, wie es zu Zeiten seines BEGRÜNDERS war, des so entschieden gegen die Pharisäer kämpfte, von denen auch das sogenannte Mündliche Testament, d.i. der Talmud, abstammt. (Vergl. Markus, VII, 7-8, Matth. XV, 2-6). Wie wir aus diesen Stellen ersehen, erkannte der Erlöser, dass diese mündliche Satzung das mosaische Recht nicht nur verdecke, sondern bisweilen sogar aufhebe. Indem die Karaimen in ihrer Glaubenslehre gegen den Talmud auftreten, fußen sie auf Worten aus den Fünf Büchern, wo entschieden erklärt wird: „Ihr sollt den Worten die ich euch heisse, weder etwas hinzufügen, noch ihnen etwas nehmen, damit ihr die Gebote des Herrn, eures Gottes, bewahrt, die ich euch heiße” (Deuteronium IV, 2). Wenn die Karaimen Jesus Christus anerkennen, so berücksichtigen sie dabei seine Worte: „Glaubt nicht, dass Ich; gekommen bin, um das Gesetz oder die Propheten aufzulösen; ich bin nicht gekommen, um aufzulösen, sondern um zu erfüllen. Denn wahrlich sage ich euch: Bis Himmel und Erde vergehen, wird nicht das Geringste vom Testament vergehen, damit alles geschehe”. (Matth. V, 17-18). [2r]

Wenn die Karaimen infolgedessen die Talmudisten für Abtrünnige vom wahren Glauben ansehen, gestatten sie ihren Mitbekennern nicht, irgendwelche Beziehungen mit den Talmudisten zu unterhatten und lassen unter keinen umständen Eheschließungen mit ihnen zu.

Dies alles, was wir hier in karaimischer Fassung bringen, wird in vollem Umfange von christlichen Theologen, insbesondere von orthodoxen Hierarchen bestätigt. In Deutschland, wo es nur höchstens 10 Karaimen gibt, sind sie gänzlich unbekannt. Wir wollen sehen, was Geistliche christlicher Bekenntnisse sagen, die die Karaimen gut kennen.

Der katholische Geistliche Nikodem Lubomir Cieszyński, der die karaimische Religion und das Leben der Karaimen in Polen speziell studiert hat, widerlegt in seinem Artikel „Die kleinste Minderheit in Polen” in höchst kategorischen Worten die Behauptungen verschiedener „Enzyklopädien”, die die karaimische Glaubenslehre als eine jüdische Sekte bezeichnen ${ }^{5}$.

4 Prof. I. G. Troitzkij, „Vom Talmud, seiner Herkunft, Zusammenstellung und Anwendung bei neuzeitlichen Juden eine Charakteristik des Talmuds von seiten seines Inhalts. Petersburg 1901. Hier beruft sich auf Seite 17 der Verfasser auf das berühmte Werk des Metropoliten Filaret: „Abriss der orthodoxen biblischen Geschichte”, 1840, Seite 463. [Przypis oryginalny].

5 Katholische Jahrgänge, Posen, Seite 323-331. [Przypis oryginalny]. 
Was die orthodoxe Geistlichkeit anbetrifft, so äußert sich z.B. der Erzbischof Hermogen, als ehemaliger Diözesalbischof in der Krim, dem Hauptmittelpunkt karaimischer Bevölkerung, über die Lehre der Karaimen wie folgt: „Sie erkennen Jesus Christus als großen Propheten und gerechten Mann an, der unschuldig gelitten hat". Die gegenwärtig als Emigranten lebenden Würdenträger der orthodoxen Kirche - die Metropoliten Eulogius und Seraphim, haben auch ihre Meinung über die Karaimen geäußert. Der erste von ihnen spricht folgend entlassen: Die orthodoxe Kirche hat den karaimischen Glauben immer für einen ganz eigenartigen gehalten und hat ihn niemals mit dem jüdischen verwechselt. Die karaimische Religion erkennt das Alte Testament mit den Zehn Geboten an, die von allen monotheistischen Religionen (wie z.B. von der mohammedanischen) übernommen worden sind. Die karaimische Lehre erkennt Jesus Christus und Mohammed als große Propheten an und verwirft den Talmud, der die Basis und die Grundlage der jüdischen Religion bildet ${ }^{7}$.

Der Metropolit Seraphim äußert sich folgendermaßen: „Der karaimische Glaube wird nach der Beurteilung der russischen orthodoxen Kirche für eine gänzlich eigenartige Religion angesehen. Die russische Regierung hat in zahlreichen Gesetzen die gänzliche Selbstständigkeit der karaimischen Religion bestätigt und hat den Karaimen volle Bürgerrechte ohne irgendwelche Beschränkungen verliehen". ${ }^{8}$

Es sind schon also mehr als 1200 Jahre vergangen, seit sich das karaimische Glaubensbekenntnis entgültig gestaltet hat und es ist seit dieser Zeit in verschiedene völkische Gruppen durchgesickert. Den Hauptkern der jetzigen Karaimen bilden Türken der Abstammung nach - die Nachfahren der einst im Süden des gegenwärtigen Russlands herrschenden Chasaren und Komanen (Polowzen). Diese Karaimen halten ihren Gottesdienst in alt-türkischer Sprache ab, die dem „Codex Cumanicus” nahesteht, dem einzigen in unsere Zeit hinübergeretteten Denkmal der komanischer Sprache, der im XIII Jahrhundert von katholischen Missionaren verfasst wurde und Bruchstücke der Evangelien, Gebete und andere Texte enthält. In dieselbe Sprache wurde auch die karaimische Bibel übersetzt, die die Karaimen sowohl im kirchlichen Gottesdienst als auch in häuslicher Gemeinschaft gebrauchen. [2v]

Von der Verbundenheit des Karaimentums mit dem Christentum war schon oben die Rede. Hier wollen wir noch hinzufügen, dass der Karaismus im Stadium seiner Gestaltung sich unter dem Einfluss der Nestorianer befand, die zu jenen Zeiten. seine nächsten Nachbarn waren. Was ihr Verhältnis zum Islam

6 Sieh das Buch „Die Taurische Diözese”, Pskow 1887 Seite 106. [Przypis oryginalny].

7 Sieh die beigefügte Abschrift seines Briefes von 5. November 1941. [Przypis oryginalny].

$8 \quad$ Sieh die beigefügte Abschrift seines Briefes von 5. November 1941; No 917.

[Przypis oryginalny]. 
anbetrifft so standen die Karaimen, die Mohammed als göttlichen Propheten anerkannten, der den Arabern gesandt war, um sie vom Götzendienst abzuwenden, unter dem ausschließlichen und starken Einfluss der theologischen Lehre des Imam A'zam Abu-Hanifa, des Begründers der chanafitischen Lehre. Bekanntlich hat Abu-Hanifa in seine Glaubenslehre den Grundsatz des „Kijas”, d.h. die Analogie, eingeführt. Die Karaimen wenden sie oft an bei der Entscheidung verschiedener Fragen, die aus der Bibel hervorgehen und wenn dort selbst kein unmittelbarer Fingerzeig zu finden ist. Als Beispiel verweisen wir auf die Präge der Eheschließungen, die zwischen nahen Verwandten verboten sind. In den Fünf Büchern (Leviticus, cap. XVIII, 6-18) ist kein kategorischer Hinweis vorhanden, der die Eheschließungen zwischen Oheim und Nichte verböte und deshalb kommen bei den Juden solche Eheschließungen oft vor, die bei den Karaimen streng verboten sind. In diesem Falle wenden die Karaimen das Gesetz der muselmänischen Theologie an nach dem. Grundsatz der Analogie nach Abu-Hanifa, nämlich, wenn gesagt ist: „Du sollst die Scham deines Vaters Schwester und deiner Mutter Schwester nicht aufdecken” (Leviticus, XVI, 12-13), d.h. mit anderen Worten, wenn es verboten ist, seine Muhme väterlicherseits oder mütterlicherseits zu heiraten, so kann auch eo ipso, nach der Analogie, der Mutters Bruder oder des Vaters Bruder nicht seiner Schwester oder seines Bruders Tochter heiraten. Schon allein diese breite Anwendung muselmännischen Rechts für die Auslegung der Bibel des Alten Testaments offenbart die Kluft zwischen der karaimischen und der jüdischen Religion.

Wir waren weit entfernt davon, eine theologische Abhandlung, über die Religion der Karaimen zu verfassen, unsere Aufgabe bestand nur darin, eine kurze Charakteristik dieser Religion zu geben. Indem wir hiermit unseren kurzen Abriss zu Ende bringen, können wir zu dem, was wir vorausgeschickt haben, wieder, zurückkehren. Wenn der Verfasser des Werkes „Histoire des origines du, christianisme”, der durch diese Werk weltberühmt gewordene Professor Ernst Renan sagt, dass „Franzosen Juden durch ihre Religion” seien, so müssen wir nach der Analogie auch anerkenne, dass alle christlichen und muselmännischen Völker nichts anderes sind, als jüdische Sektierer. Natürlich haben die Karaimen auch keinen Grund, in dieser allgemeinen Bestimmung des Religionsbegriffes eine Ausnahme zu bilden.

Wilna, den 23 April, 1942.

Gez: Prof. H. S. Schapschal 


\section{[11.07.1942]}

LMAVB RS F 143-928, f. 1r-6r

Stempele Giulio Fochi, Beglaubigte Übersetzung

Studium Urbis, Rom (30), den 6 Juni 1942, via delle Terne [s] di Diocleziano

Italienischer Ausschuss

Für das Studium der Bevölkerungsfragen

Der Präsident,

Der Italienische Ausschuss für das Studium der Bevölkerungsfragen, hat im Jahre 1934 eine Untersuchung über die besonderen demographischen, anthropometrischen und sonstigen körperlichen Merkmale der Karaimen in Polen und Litauen durchgeführt und dabei ausführliche Mitteilungen und Unterlagen über 158 Familien und mehr als 550 Personen gesammelt Außerdem wurden bei 552 Personen die Blutgruppen ermittelt. Der untersuchte Bevölkerungsteil umfasst somit mehr als 2/3 der in Polen und Litauen wohnenden Karaimen.

Der Leiter dieser vorzüglich ausgerüsteten Studienfahrt war Prof. Corrado Gini, der Vorsitzende des genannten Ausschusses und Dekan der Fakultät für Statistische, Demographische und Archiv-Wissenschaften der Kgl. Universität Rom. An der Studienfahrt nahmen überdies zwei italienische Assistenten der genannten Fakultät und 7 polnische Wissenschaftler, d.h. Spezialisten für demographische, anthropometrische und medizinische Fragen teil.

Bei diesen Untersuchungen erfreute sich der Ausschuss der Unterstützung und Mitarbeit der polnischen Behörden sowie der karaimischen kirchlichen Behörden. Dank dieser Unterstützung durch einflüßreiche Persönlichkeiten zeigte sich die Bevölkerung gern zur Mitarbeit bereit. Auch dieser umstand hat dazu beigetragen, dass Ergebnisse erzielt wurden, die als völlig befriedigend bezeichnet werden dürfen.

Vorerst sind die auf die Blutgruppen bezüglichen Ergebnisse vollständig ausgewertet worden. Sie wurden deshalb zuerst durchgearbeitet, weil die karaimische Bevölkerung von dem Wunsch beseelt war, den Nachweis ihrer rassenmäßigen Zusammensetzung zu erbringen.

Die Karaimen besitzen nämlich ein starkes Gefühl der Zusammengehörigkeit und möchten unter keinen umständen mit den Juden verwechselt werden. Aus dieser Einstellung heraus hofften sie zuversichtlich, dass die Ergebnisse der Blutgruppenuntersuchungen ihre mutmassliche turko-tatarische Herkunft bestätigen würden.

Die erzielten Ergebnisse bestätigten in der Tat die Vermutung, dass die karaimische Bevölkerung in Polen und Litauen sich von der jüdischen Bevölkerung 
unterscheidet, und sogar noch deutlicher, als dies bei den Turko-Tataren der Fall ist. Der Vergleich ihrer blutgruppenmäßigen Zusammensetzung mit der Zusammensetzung anderer osteuropäischer Volksstämme lässt in der Tat die durchaus begründete Annahme zu, dass die karaimische Bevölkerung in Polen und. Litauen im wesentlichen der ugrisch-finnischen Rasse angehört, wenn sie auch heute eine türkische Mundart spricht und wahrscheinlich eine ziemlich starke Beimischung turko-tatarischen Blutes besitzt.

Noch stärker scheint diese Beimischung turko-tatarischen Blutes bei den Krimkaraimen zu sein, die auch dann noch in ständiger Berührung mit den turko-tatarischen Volksteilen geblieben sind, als die polnischen und litauischen Karaimen sich bereits von ihnen abgesondert hatten.

Für dieses Ergebnis ließen sich in historischer Einsicht verschiedene Erklärungen finden. Wir können uns sehr wohl die Ansicht einiger Forscher zueigen machen, dass die Karaimen nicht von den Kasaren oder von den Kumanen abstammen, sondern vielmehr von den taurisch-kimmerischen Volksstämmen ugrischen Blutes, die vor den Kasaren auf der Krim wohnten. Es ist aber auch möglich, dass die Karaimen doch von den Kasaren abstammen, dass die letzteren aber ugrischer Rasse waren, wenn sie auch eine turko-tatarische Mundart angenommen hatten. Endlich ist auch möglich dass das Reich der Kasaren, ebenso wie das der Kumanen, ein Konglonerat aus verschieden ungarischen und turko-tatarischen Stämmen darstellte und dass die durch den Grossherzog Withold in das heutige Gebiet von Polen und Litauen überführten karaimischen Familien mehr ugrisches als turko-tatarisches Blut besaßen.

Bei den Karaimen in Polen und Litauen scheinen die Dinge in rassischer und sprachlicher Hinsicht ähnlich zu liegen wie bei den Tschuwaschen, die bekanntlich ugrischer Rasse sind und später die turko-tatarischen Sprache angenommen haben. Die Tschuwaschen weisen nämlich eine ähnliche Blutgruppen-Zusammensetzung auf wie die Karaimen in Polen und Litauen.

Die Auswertung der anthropometrischen Feststellungen ist noch nicht beendet; es ist aber anzunehmen, dass sie an den auf Grund der Blutgruppenuntersuchungen erzielten Schlussfolgerungen keinesfalls mehr etwas ändern können, weil alle anthropometrischen Merkmale in höherem Grade, als dies bei den Blutgruppen der Fall sein könnte, den Einwirkungen der Umwelt unterliegen und infolgedessen hinsichtlich der rassenmäßigen Zusammensetzung der Völkerschaften weniger zuverlässige Anhaltspunkte liefern.

Die Schlussfolgerungen, zu denen die Teilnehmer der obengenannten Studienfahrt gelangten, sind in dem Aufsatz „Die Karaimen in Polen und Litauen” in der Zeitschrift „Genus”, dem im Auftrag des Nationalrates für Forschungen herausgegebenen Organ des Italienischen: Ausschusses für das Studium der Bevölkerungsfragen dargelegt (Band II, nr. 1-2, Juni 1936). Diese Schlussfolgerungen sind kürzlich auch in dem Band zusammengefasst worden, der den Titel 
trägt „Statistische Erhebungen bei den primitiven Völkerschaften” (Manuali universitari della R. Università di Roma, Dritte Ausgabe 1942, S. 86-87). Der auf die vorliegende Frage bezügliche Passus lautet:

„Oft legen die primitiven Völkerschaften großen Wert auf die Reinheit ihrer Rasse, und diese Reinheit kann in manchen Fällen durch die Untersuchung der Blutgruppen festgestellt. werden. Dergleichen Einstellung begegnen wir übrigens auch bei nicht primitiven Völkerschaften. So z.B. bei den Karaimen, die gerade von der Blutgruppenuntersuchung den zuverlässigsten Beweis dafür erwarteten, dass sie in Hinsicht ganz und gar nichts mit den verhassten Juden zu tun haben, dass sie vielmehr eng mit den turko-tatarischen Völkerschaften verwandt sind, deren Sprache sie heute noch sprechen und von denen sie ihrer Meinung nach abstammen. Die Blutuntersuchung hat Ergebnisse gezeitigt, die ihre kühnsten Erwartungen sogar noch übertrafen. Diese Ergebnisse haben nämlich gezeigt, dass die Karaimen sich in ihrer Blutzusammensetzung sogar noch viel stärker von den Juden unterscheiden, als dies bei den Türko-Tataren der Fall ist, so dass die Annahme durchaus glaubhaft erscheint, dass die kasarischen Völkerschaften, von denen die Karaimen vermutlich abstammen, in Wirklichkeit nicht turko-tatarische, sondern ugrisch-finnische Stämme waren, die, wie dies bekanntlich auch bei anderen Völkerschaften, z.B. bei den Tschuwaschen der Fall gewesen ist, die türkische Sprache angenommen haben.”

Gez. Corrado Gini

Der Unterzeichnete bescheinigt, bezugn. auf den ein für allemal geleisteten Dolmetßchereid, dass die vorliegende Übersetzung in deutscher Sprache mit dem in italienischer Sprache abgefassten Original übereinstimmt.

Berlin-Charlottenburg, den 11.7.1942, Schlossstr. 16

gez. Giulio Fochi

\section{[4.08.1942]}

LMAVB, F 143-1038, f. 97r

Wilna, 4 August 1942

Betrifft: Deutschlandsreise des Karaimischen Erzbischofs

An den Kommendeur für Urlauber-Überwachung. Wilna.

Exc. Hachan Schapschal, karaimischer Erzbischof und Prof. der Universität Wilna hat von zuständiger Stelle den Auftrag erhalten eine Gescichte der Karaimen zu schreiben. Zum Studium einschlägiger Literatur reist er am 15. August nach Berlin. 
Es ist z.Z. nicht möglich von hier einen Offizier zur Begleitung abzustellen, wie dies in einem ähnlichen Fall früher geschehen ist. Doch dürfte es möglich sein, einen am fraglichen Tag nach Berlin reisenden Offizier zu beauftragen Exc. Hachan Schapschal während der Reise zu betreuen.

Unter Bezugnahme auf das heutige Ferngespräch wird gebeten dafür Sorge zu tragen, dass Exc. H. Sch. Im D-Zug nach Berlin einen Sitzplatz bekommt und beim Grenzübertritt durch einen mitreisenden Offizier unterstützt wird.

Exc. H. Sch. Hat die Einreiseerlaubnis der zuständigen zivilen Dienststelle.

Kommandant des Feldkommandanturbereiches Wilna

Gez. Hauptmann

\section{[7.09.1942]}

LMAVB RS F 143-1082, fol. 5r-5v

An Seine Exzellenz Herrn Generalkommissar in Vilna

\section{[5r]}

Der Verordnung über die Rechtsverhältnisse religiöser Organisationen vom 19 Juni 1942 (Amtsblatt des Generalkommissars in Kauen, Nr. 31/32 vom 25 Juni 1842) gemäss beehre ich mich, Ihnen mitteilen zu dürfen:

1) Das Oberhaupt der karaimischen Bekenntnisgemeinschaft für ganz Europa ist Hachan der Karaimen. Seit dem Jahre 1915 bekleide diese Würde ich, Hadży Seraja Chan Schapschal, geb. am 20 Mai 1873 auf der Krim in Bachyschesaraja. Meiner Kompetenz unterlagen und unterliegen in religiösen Angelegenheiten alle in Europa ansässigen Karaimen. In Jahren 1915 bis 1918 hatte ich meinen Sitz in Eupatoria auf der Krim, in Jahren 1918 bis 1928 wohnte ich als Emigrant in Konstantinopel; seit dem Mai 1928 bin ich in Wilna ansässig, wo jetzt im Hause Nr. 17 in der Kęstutis-Strasse wohne.

2) ich bin Vorstandsvorsitzender des Geistlichen Konsistoriums der Karaimen, dessen Sitz Traken (Trakai) sind. Dieser Vorstand ist kollegial und macht ein mich in religiösen Angeleigenheiten beraten Organ aus. Seinen Bestand bilden ausser mit Vorsitzenden 2 Mitglieder: Ułłu-hazzan und Pfarrer der Trakener Kenesse - Simon Firkowitsch und hazzan-Pfarrer der Wilnaer Kennesse - Rafael Firkowitsch.

3) Unterstellte örtliche Organen bilden die Vorstände der Karaimengemeinden. Es gab und gibt im Gebiet des Generalkommissariats [5v] Kauen drei, und zwar die Gemeinden Traken, Wilna und Ponevežys.

Zugleich habe ich die Ehre, Ihnen ein Exemplar der ins Deutsche übersetzten und in Übereinstimmung mit dem Weisungen der Organe des 
Gebietskommisars Wilno-Stadt den Erfordernissen der jetzigen Zeit angepassten Satzung der karaimische Religionsgemeinschaft vorzulegen. Ich vertrete diese Gemeinschaft, wir aus dem Obigen erhellt, nicht nur im Ostland, sondern auch in der Ukraine und vornehmlich auf der Krim, wo zahlreiche Zusammenhäufungen und Tempel der Karaimen vorkommen.

1 Beilage.

Wilna, den 7 September 1942

\section{[14.11.1942]}

LMAVB, F. 143-1082, fol. $8 \mathrm{r}$

Dr. habil. Fritz Steiniger

Institut für medizinische Zoologie

Reichskommissar für das Ostland

Riga-Kleistenhof

Riga, den 14.11 .1942

Herrn

Professor Hadschi Sereja Schapschal

Hachan der Karaimen

Wilna

Kęstuziostr. 17.

Sehr geehrter Herr Professor!

Die Untersuchung der Karaimen in Wilna soll am 6. Dezember, in Traken am 7. Dezember stattfinden. Herr Dr. Holtz, der vom Reichsministerium für die besetzten Ostgebiete dazu herkommt, möchte in Wilna auch die dortigen Mohamedaner ebenfalls untersuchen. Würden Sie bitte die Freundlichkeit haben, bei dem Herrn Mufti oder dem Herrn Imam entsprechendes mit zuteilen und am eine Unterstützung der Untersuchung zu bitten?

Wegen Ihrer Gehaltsschwierigkeiten habe ich sowohl an das Reichsministerium für die besetzten Ostgebiete als auch an das Generalkommissariat in Kauen geschrieben. Vielleicht haben Herr Dr. v. Lilienfeld-Toal und Herr Dr. Bernsdorff, die in diesen Tagen nach Wilna kommen, schon dafür gesorgt, dass Sie zu Ihrem Recht kommen.

Bei Ihrem Aufenthalt in Riga war leider ein Besuch bei Herrn Regierungsrat Trampedach nicht möglich, da dieser eilig verreisen musste und daher keine Zeit hatte.

Heil Hitler!

/-I 


\section{[20.11.1942]}

LMAVB RS F 143-1080, fol. 1r-3r

Wykaz członków karaimskiej gminy w Wilnie w wieku od 20 do 50 lat.

1. Abkowicz Rafal, ur. 1896

2. Czaprocki Daniel, ur. 1895

3. Dubińska Sofia, ur. 1916

4. Dubińska Nina, ur. 1908

5. Dubińska Elżbieta, ur. 1893

6. Firkowicz Julian, ur. 1917

7. Jutkiewicz Michal, ur. 1901

8. Jutkiewicz Arkadiusz, ur. 1897

9. Jutkiewiczowa Helena, ur. 1905

10. Jutkiewicz Józef, ur. 1910

11. Jutkiewiczowa Olga, ur. 1918

12. Juchniewicz Helena, ur. 1900

13. Juchniewicz Leon, ur. 1892

14. Juchniewiczowa Katarzyna 1895 [1v]

15. Kapłanowska Zofia, ur. 1917

16. Kapłanowska Elwira, ur. 1916

17. Kobecki Jerzy, ur. 1921

18. Kobecka Natalia, ur. 1922

19. Kobecki Michał, ur. 1905

20. Kobecka Anna, ur. 1904

21. Kozyrowiczowa Raisa, ur. 1892

22. Kozyrowicz Aleksander, ur. 1914

23. Kozyrowicz Marek, ur. 1921

24. Eopatto Zinaida, ur. 1894

25. Łopatto Sofia, ur. 1899

26. Eopatto Zofia, ur. 1901

27. Łopatto Konstanty, ur. 1896

28. Łopatto Dina

29. Łopatto Eliasz, ur. 1895

30. Łopattowa Kamila, ur. 1893

31. Łopato Gabriel, ur. 1900

32. Łopattowa Raisa, ur. 1899

33. Łopatto Raisa, córka Szym[ona], ur. 1897

34. Michajłowicz Rafal, ur. 1912 [2r]

35. Michajłowicz Szymon, ur. 1904

36. Michajłowiczówna Anna, ur. 1907 
37. Michajłowiczówna Nina, ur. 1912

38. Michajłowicz Jakób, ur. 1914

39. Nowicka Zofia, ur. 1900

40. Robaczewski Szymon, ur. 1897

41. Robaczewska Berta, ur. 1898

42. Rojecki Ananiasz, ur. 1896

43. Rojecka Nadzieja, ur. 1894 [dopisek ołówkiem:] Rojecki Jonas -

44. Pilecki Leon, ur. 1903

45. Pilecki Izaak, ur. 1903

46. Pilecka Anna, ur. 1891

47. Pilecki Edward, ur. 1905

48. Pilecki Eliasz, ur. 1917

49. Szulimowicz Marek, ur. 1911

50. Szulimowicz Walent[yna]

51. Szyszman Szymon, ur. 1909

52. Szyszman Michał, ur. 1910

53. Szpakowska Elmira, ur. 1900

54. Szyszmanowa Zinaida, ur. 1900 [2v]

55. Szyszman Daniel, ur. 1921

56. Szpakowski Michał, ur. 1912

57. Szpakowska Tamara, ur. 1913

58. Szpakowska Zofia, ur. 1903

59. Szpakowski Adolf, ur. 1905

60. Szpakowska Eugenia, ur. 1907

61. Szpakowska Nina, ur. 1912

62. Zajączkowski Aleksan[der], ur. 1903

63. Zajączkowska Anna, ur. 1896

64. Zajączkowski Jakób, ur. 1900

65. Zajączkowska Zofia, ur. 1903.

66. Zajączkowska Nadzieja, ur. 1895

67. Zajączkowski Włodz[imierz], ur. 1914

68. Michajłowiczówna Luba

69. Dubiński Michał

70. Kapłanowski Michał

71. Kapłanowska Anna

72. Tinfowicz Michał

73. Tinfowiczowa Raisa

74. Malecki Eugeniusz [3r]

75. Rojecki Julian

76. Pilecki Eugeniusz 
77. Nowicki Eugeniusz

78. Chorczenko Basia, ur. 1892

Wykaz sporządził hazz[an] R. Abkowicz

20.XI.1942 r.

Vilnius

\section{[6.01.1943]}

LMAVB, F 143-1082, fol. 9r

Nationalsozialistische Deutsche Arbeiterpartei. Rassenpolitisches Amt

Berlin W 15, 6. Januar 1943

Herrn Professor Schapschal

Wilna

Sehr geehrter Herr Professor!

Meine Abreise von Vilna erfolgte s. Zt. so plötzlich, daß es mir nicht mehr möglich war, Ihrem Anerbieten, mir die Kinessa der Karaim in Wilna zu zeigen zu folgen. Ich bitte Sie, in Anbetracht der Umstände höflichst um Entschuldigung.

Zugleich möchte ich eine Bitte, die ich Ihnen bereits in Wilna vortrug, äußern. Es handelt sich um die Frage, ob der im Jahre 1888 am 22. Juli.in Rezina (Rumänien) als Sohn des Sloima Malamud und seiner Frau Basea geborene Duvid-Ghers Malamud, der von einer jüdischen Rabbiner beschnitten wurde und karaimischer, d.h. nicht-jüdischer Abstammung zu sein behauptet, Ihnen als Karaime bekannt ist. Ich wäre Ihnen für Ihre Auskunft sehr verbunden.

Zugleich bitte ich Sie nochmals um die Anschrift des Vertrauensmannes der Karaim in Berlin. Die Anschrift ging mir leider verloren. Ich wäre Ihnen dankbar, wenn Sie Ihre Antwort über die Deutsche Dienstpost, und zwar am zweckmäßigsten über das Gebietskommissariat Wilna-Stadt befördern könnten, da ich so eher Nachricht erhalte. Ich hafte, Sie bei Gelegenheit in Wilna wieder aufsuchen zu dürfen und möchte Ihnen nochmals für Ihr.großes Entgegenkommen danken.

Mit den besten Empfehlungen an Sie selbst und Ihre sehr verehrte Frau Gemahlin!

Heil Hitler!

gez. Dr. Holtz 


\section{[10.08.1943]}

LMAVB F 143-1038, f. 36r

Hachan der Karaimen in Wilna

Wilna, den 10 August 1943

Kęstucio Str. 17

An Herrn Generalkommissar in Kauen

Durch Herrn Gebietskommissar Wilna-Land

Betrifft: Arbeitseinsatz der Karaimen

Die karaimische Bevölkerung in den Grenzen der früheren Litauischen Republik ist in geistlicher Hinsicht in drei Religionsgemeinden mit Tempeln in den Städten - Traken, Wilna und Ponewesch - geteilt and stellt eine zahlenmässig geringe ethnologische Gruppe von ungefähr 500 Personen dar.

Die Haupttätigkeit der.Karaimen besteht in der Landwirtschaft und dem Gemüsebau. Die Intelligenz der Karaimen ist in Staatsdiensten beschäftigt.

Bis jetzt ist von hier bereits der einberufene Teil sowohl Männer, als auch Frauen ins Reich zur Leistung des Arbeitsdienstes fortgefahren. Auch was die Krim anbetrifft, wo die karaimische Bevölkerung in der Hauptsache konzentriert ist, so sind auch von dort, zusammen mit den Tataren, mehrere Hundert der karaimischen Jugend ins Reich zum Arbeitsdienst hingefahren.

In Anbetracht dessen, dass auf Grund der bevorstehenden ArbeitsdienstEinberufungen weitere örtliche Karaimenjugend in Reich verreisen wird müssen, wodurch sich der Hundersatz der Einberufungen, im Hinblick auf die geringe Zahl der Karaimen überhaupt. Bedeuten vergössert, würden unsere Gemeinden stark menschenleer werden !

Nichts destoweniger, sind sich die Karaimen ihrer bürgerlichen Pflicht vollbewußt und.niemand von ihnen denkt daran, sich irgendwie von der Erfüllung der Pflichten zu drücken.

In Anbetracht des obendargelegten erlaube ich mir, den Herrn Generalkommissar ergebenst zu bitten, dem kleinen Häuflein der karaimischen Bevölkerung Litauens insofern helfend, entgegen zu kommen indem Sie verfügen wurden, dass die nunmehr zur Einberufung kommende karaimische Jugend, den Arbeitsdienst in der Nähe ihrer beständigen Wohnorte und somit in der Nähe ihrer Tempel verrichten dürfte.

Für die eingegenkommende Erfüllung der ergebensten Bitte gestatte ich mir schon jetzt meinen heißempfundenen Dank auszusprechen.

Die Liste der demnächst zur Arbeitsdienst-Einberufung kommenden Karaimen füge ich. hier bei.

Mit aller Hochachtung ergebenst

/-I 


\section{[10.11.1943]}

LMAVB, F 143-1038, f. 98r

Johannes Jacob, Architekt und Baumeister

Mitglied der Reichskammer der Bildenden Künste

Stahnsdorf (Teltow), 10. November 1943

Sehr geehrter Herr Professor,

Ich verdanke Ihre Adresse einem Artikel in der „Deutschen Allgemeinen Zeitung" des Herrn Bergemann vor einigen Wochen und wollte mir erlauben, Ihre Sachkenntnis als Sprachforscher bezw. Ihre Hilfe in einer für mich sehr wichtigen Angelegenheit in Anspruch zu nehmen. Es ist mir ferner bekannt, daß Sie als Führer einer besonderer Volksgruppe für derartige Sorgen wie die meinen Verständnis haben werden. Es handelt sich etwa um eine gutachtliche Äußerung über die Abstammung eines Namens, und zwar über den meiner Schwiegermutter, für deren Herkunft sich ein Nachweis durch Urkunden nicht erbringen läßt.

Der Name lautet Tatjana. Akjimowna Paperne (Vater Akjim Fjodorow Paperne, Mutter: Isabella Wassilowna Paperne, geb. Bogoslav), Religion: katholisch ${ }^{70}$.

Meine bisherigen Nachforschungen haben ergeben, daß der Name auf eine italienische Abstammung hinweist. Ich habe bisher in anderen Sprachen keinerlei Verwandtschaft entdecken können. Im Glossarium Hentschel von Domino du Cange, dem bekannten lateinischen Wörterbuch, Band V P-R, findet sich das Wort paperni als Abkürzung von Paparini. Das Wort bedeutet eine alte italienische Münze. Das Paperne dasselbe Wort wie Paperni sein kann, liegt wohl sehr nahe. Derartige Vokaländerungen im Auslaut eines Namens sind wohl ohne Bedeutung. Der Personennahme Paperini ${ }^{71}$ ist in Rom noch heute üblich, auch ähnliche Namen, wie Paperni. Ferner habe ich erfahren, daß es noch heute eine italienische Kolonie in Wilna geben soll, die von Bauleuten abstammt, welche im 18. Jahrhundert Kirchen im Barockstil erbaut haben sollen.

Vielleicht wäre es möglich, die Adresse einer prominenten Persönlichkeit aus dieser italienischen Kolonie zu erfahren, die über derartige, Namensabstammungen eine Auskunft geben könnte. Vielleicht bestehen auch Kirchenbücher über diese italienische Gemeinde in Wilna.

Der Name Paperne soll in Wilna auch bei Juden vorkommen. Das würde aber an der ursprünglich italienischen Abstammung des Namensträger nichts

70 Na marginesie ołówkiem: Alle aus Wilna.

71 Słowo przekreślone, na marginesie ołówkiem: Paparini. 
ändern. An Hand der Kirchenbücher müßte sich wohl feststellen lassen, ob der Name früher oder auch jetzt noch bei Katholiken vorkommt.

Jedenfalls danke ich Ihnen im Voraus für jeden Hinweis oder jede Hilfe auf dem schwierigen Wegs der Abstammungsforschung, die Sie mir vielleicht gewähren könnten. Natürlich scheue ich auch keine entstehenden Kosten.

Mit vorzüglicher Hochachtung und Heil Hitler

/Johannes Jacob/

\section{[1943]}

LMAVB RS F 143-1337, fol. 1r-1v

Herbert Kirrinnis, Die Karaimen, Sonderabdruck aus Petermanns Geographischen Mitteilungen, 1943, Heft 3-4, s. 100-101

Bis in die jüngste Zeit ist die Einordnung der Karaimen in größere Völkerfamilien und besonders ihre Zuordnung zu verwandten religiösen Gemeinschaften auf Schwierigkeiten gestoßen. Es handelt sich dabei - das sei gleich vorweggenommen - nicht um ein jüdisches, sondern um ein türk-tatarisches Volk, das rund 13000 Menschen zählt und heute um seine Behauptung ringt.

In der Krim saßen vor dem Kriege etwa 12000 Karaimen; durch die Bolschewistenherrschaft ist ihre Zahl sicherlich zurückgegangen. Sie wohnen dort in den größeren Städten Eupatoria, Simferopol, Feodosia, Sewastopol, hatten auf dem Lande aber ihre Grundstücke, betrieben also Landwirtschaft, Gartenwirtschaft, pflegten mit besonderer Sorgfalt den Obstbau und führten dabei eine Art nomadenhaftes Dasein. Neben diesen Krim-Karaimen finden sich weitere 1000 eigenartigerweise im polnisch-litauischen Siedlungsraum. Ihre Zahl beläuft sich bei Luzk-Halicz auf rd. 250, in der Stadt Wilna selbst auf 250 und in Traken ( $25 \mathrm{~km}$ wsw Wilna), dem Mittelpunkt der polnischlitauischen Karaimen, auf etwa 350. Ihr nördlichstes Siedlungsgebiet erreichen sie mit rd. 160 Köpfen um Poniewisch. An der Spitze des karaimischen Volkes steht als politisches und geistliches Oberhaupt zugleich der Hakhan, z. Zt. Prof. Hadschy Seraja Schapschal-Wilna, dem der Verfasser für die Auskünfte an dieser Stelle seinen Dank sagt. In Wilna sind die Karaimen meist Beamte, Kaufleute oder Handwerker, beschäftigen sich aber in den anderen Orten vorzugsweise mit Ackerbau; die Karaimen-Gurken, deren Samen aus der Krim mitgebracht wurden, sind z. B. weithin bekannt. Die Menschen selbst tragen ein fremdartiges Gepräge. Der türkisch-tatarische Typ ist bei Männern und Frauen unverkennbar. Dagegen zeigen die Häuser und auch die Wohnungen selbst kaum Eigenarten. Das gilt gleichfalls für die Kleidung. 
Dennoch sind sie traditions-bewußt und hängen an ihren Sitten und Gebräuchen. In den Karaimenmuseen in Traken und Wilna kann man sich mit ihrer materiellen und geistigen Kultur näher beschäftigen und wird erkennen, daß es sich um ein Volk handelt, das seine Heimat im Vorderen Orient hat und der Schwarzmeer-Kultur zugehört. Das Auftreten der Karaimen in Polen-Litauen hat historische Ursachen. Der große Gegner des Deutschen Ordens in der Tannenberger Schlacht 1410, der litauische Großfürst Withold (lit. Vytautas) war im Jahre 1398 bis an das Schwarze Meer vorgedrungen. In der Krim hatte er als Kontribution von der unterworfenen Bevölkerung die Gestellung von 15.000 Soldaten gefordert, die nach ihrer Umsiedlung in das westliche Litauen als Grenzwacht gegen den Orden angesetzt wurden. Da sie dem Waffenhandwerk sein zugetan waren und sich im Kampf stets als tapfer erwiesen hatten, stellte eine Elite dieser Karaimen die Leibwache für den Großfürsten. In jener Zeit war die heute noch als romantische Ruine erhaltene Wasserburg Traken Witholds Residenz. In unmittelbarer Nahe, auf einer Landenge wurden diese Karaimen angesiedelt, erhielten besondere Privilegien, führten dort ihr Eigenleben, und bis in die heutige Zeit ist im polnisch-litauischen Siedlungsgebiet Traken ihr Mittelpunkt geblieben.

Die Karaimen sind türkischer Herkunft. Schon früh haben sie die Bibel und ihre Gebetbücher in die alt-türkische Sprache übersetzt und benutzen sie beim Gottesdienst noch heute. Diese Sprache steht der des „Codex Cumanicus” nahe, dem einzigen noch erhaltenen Denkmal kumanischer Sprache. Die eigenartige karaimische Lehre, die unten kurz ausgeführt wird, nahmen zu Ende des 8. Jahrhunderts u.a. die Chasaren mit ihrem Chagan an der Spitze an; gleichzeitig waren auch der Islam und das Christentum im Chasarenreich am Schwarzen Meer vertreten. Die heutigen, zum Alten Testament ohne den Talmud sich bekennenden und eine alttürkische Sprache sprechenden Karaimen sind gleichfalls als Nachkommen der einst in der Krim herrschenden Chasaren anzusehen. Zu dieser bereits früher nachgewiesenen Erkenntnis kommen auf Grund besonders eingehender Studien 1917 auch der Krim-Historiker W. Smirnoff-Simferopol und im Jahre 1934 der Wilnaer Kunsthistoriker M. Morelowski. Letzterer gelangt zu dieser Ansicht durch das Studium der geometrischen Ornamente auf den Handtüchern und anderen Webarbeiten. Die wissenschaftliche Untersuchung der karaimischen Märchen und Heldenlieder führt zum gleichen Ergebnis. Anthropologische Messungen sind an den Karaimen bereits früher vorgenommen worden, und vor einigen Jahren hat man auch Blutgruppenbestimmungen durchgeführt. Dabei kommt M. Reicher ${ }^{1}$ bei den

\footnotetext{
1 Reicher, Michel; Sur les groupes sanguiens des Caraimes de Troki et de Wilna, Zs. Anthropologie, Prag 1932. [Przypis oryginalny].
} 
Wilnaer und Trakener Karaimen zu dem Ergebnis, daß der Hundertsatz der Blutgruppe A sehr klein, der Gruppe 0 aber sehr hoch ist und weiterhin zu der Ansicht, daß sie den Tschuwaschen nahestehen, mit den Juden also, wie häufig behauptet wird, nichts zu tun haben. „Quant aux peuples turco-tatars une plus grande ressemblance se montre entre eux et les Caraimes polonais, qu'entre les derniers et les Juifs" (Schapschal nach Reicher, S. 265). Zu dem gleichen Resultat, auch hinsichtlich der Verwandtschaft der Karaimen mit den Tschuwaschen, kommt im Jahre 1934 der italienische Professor Gini², der Untersuchungen in noch größerem Rahmen durchführte als Reicher. Alexander Baschmakoff ${ }^{3}$ weist auf Beziehungen zu den Tscherkessen hin, und hinsichtlich der Familiennamen ergeben sich Zusammenhänge nach dem Kaukasus.

Die Sprachuntersuchungen, besonders durch den polnischen Professor T. Kowalski, erbringen gleichfalls den Nachweis, daß eine Verwandtschaft zwischen den Türken und den Karaimen besteht. Als Kemal-Atatürk daranging, nach der Annahme der lateinischen Schrift die türkische Sprache von Fremdwörtern, die besonders aus dem Arabischen und Persischen stammten, zu reinigen, wurden 330 karaimische Wörter wieder in den türkischen Sprachschatz aufgenommen.

Da die Karaimen sich zum Alten Testament bekennen, den Sonnabend feiern und alttestamentliche Namen bei ihnen auftreten, hat man häufig daraus den Schluß gezogen, daß sie den Juden zuzurechnen sind. Die Juden selbst, nehmen in dieser Frage eine gegensätzliche Haltung ein. Von jüdischen Mitarbeitern bei manchen Lexika, [101] in denen man meistens nur kurze Bemerkungen über die Karaimen findet, oder von mittel- und westeuropäischen Autoren wird mitunter behauptet, daß der Karaismus nur eine von Anan-Ibn-Daud wenig abgeänderte Glaubenslehre ist, die zu Beginn des 8. Jahrhunderts in Babylon sozusagen als politische Opposition gegen das damalige Judentum entstanden sei. In Werken dagegen, die nur für Juden bestimmt sind, behaupten die jüdischen Verfasser selbst bis in die jüngste Zeit, daß der Karaismus mit der jüdischen Lehre nichts Gemeinsames habe, mit dem Islam und dem Christentum aber in vielen Auffassungen sich berühre. Allgemein wird in diesem Zusammenhang die radikale Ausrottung der Karaimen verlangt, weil sie als Abtrünnige anzusehen seien. „II est permis, de les tuer”.

Wie ordnen die Karaimen ihren Glauben ein? Sie haben in ihrer Lehre die fünf Bucher und die Propheten mit dem Judentum gemeinsam, lehnen aber den zweiten Teil des jüdischen Glaubensbekenntnisses, den für das Judentum wesentlichen und bedeutsamen Talmud ab. „Die zwischen diesen beiden

2 Gini, Corrado: I Caraimi di Poloni e di Lituania, Zs. Genus, Rom, 1936. [Przypis oryginalny].

3 Baschmakoff, Alexandre: Cinquante siècles d'evolution ethnique autour de la Mer Noire. Paul Genthner, Paris 1937. [Przypis oryginalny]. 
Religionen vorhandene Kluft kann niemals und nirgends zugeschüttet werden” (Schapschal). Die Begründer des Karaismus lebten zur Zeit Jesu Christi in Palästina. Man setzt also den Ursprung dieser Lehre erheblich früher an als die Juden, die in dem Angriff Anan-Ibn-Dauds gegen den Talmud im 8. Jahrhundert nur eine Emanzipation sehen. Die Karaimen wiederum sehen in den Talmudisten Abtrünnige vom wahren Glauben, gestatten daher ihren Volks- und Glaubensgenossen keine Beziehungen und lassen unter keinen Umständen Eheschließung mit ihnen zu. Da die karaimische Lehre besonders griechisch-orthodoxen Geistlichen genauer bekannt ist, nehmen auch diese vorzugsweise zu ihr Stellung, z.B. der in der Emigration lebende Metropolit Eulogius: „Die orthodoxe Kirche hat den karaimischen Glauben immer für einen ganz eigenartigen gehalten und hat ihn niemals mit dein jüdischen verwechselt. Die karaimische Religion, erkennt das Alte Testament mit den 10 Geboten an, die von allen monotheistischen Religionen, wie z.B. der mohammedanischen übernommen worden sind. Die karaimische Lehre erkennt weiter Jesus Christus und Mohammed als große Propheten an und verwirft den Talmud, der die Grundlage der jüdischen Religion bedeutet" (Brief vom 5. Nov. [19]41). Der ebenfalls jetzt im Ausland wohnende Metropolit Seraphim äußert sich folgendermaßen: „Der karaimische Glaube wird nach der Beurteilung der russischen orthodoxen Kirche als eine gänzlich eigenartige Religion angesehen. Die russische Regierung hat in zahlreichen Gesetzen die völlige Selbständigkeit der karaimischen Religion bestätigt und hat den Karaimen volle Bürgerrechte ohne irgendwelche Beschränkungen verliehen” (Brief vom 5. Nov. [19]41). Das zeigte sich z. B. im zaristischen Heeresdienst. Die Karaimen aus der Krim stellten früher dem kaiserlichen Rußland viele Offiziere. Besondere Verdienste hatte im 17. Jahrhundert der Oberst der Saporoger Kosaken Eliasch Karaimowitsch, der selbst die Stellung eines Hetmann inne hatte. Das alles wäre unmöglich gewesen, wenn die Karaimen jüdischer Herkunft gewesen wären, da im Zarenheer Nachkommen getaufter Juden bis ins 3. Glied nicht, zu Offizieren befördert wurden. Es sei noch darauf hingewiesen, daß auch früher unter den Kosaken des Saporoger Gebiets der karaimische Glaube anzutreffen war. Ihre Nachkommen wohnen in dem Kosakendorf Michailowskaja, unweit Jekaterinodar.

Nach der Machtergreifung des Nationalsozialismus haben Juden nun häufig erklärt, daß sie Karaimen seien. Sie versuchten sich zu tarnen und brachten die Karaimen dadurch in Verruf. Durch Erlaß des Reichsministeriums des Innern vom 22. Dezember 1938 wurde dann die Karaimenfrage dahingehend geklärt. „Die Sekte der Karaimen ist nicht als jüdische Religionsgemeinschaft (...) anzusehen. Die Feststellung, daß die Karaimen in ihrer Gesamtheit artverwandten Blutes sind, kann jedoch nicht erfolgen, denn die rassische Einordnung einer Person läßt sich nicht ohne weiteres nach ihrer Zugehörigkeit zu einem bestimmten Volke, sondern immer nur nach ihren persönlichen 
Abstammungsverhältnissen und rassebiologischen Merkmalen vornehmen”. Das entspricht der ablehnenden Haltung der Karaimen gegenüber den Juden; auch die Versuche, trotz vorderasiatischer Einschläge der Karaimen eine jüdische Abstammung herzuleiten, sind abwegig. Sie gehören zu den türk-tatarischen Völkern, von denen durch die Stürme der osteuropäischen Geschichte einige Splitter bis in das polnisch-litauische Siedlungsgebiet verschlagen worden sind, und bewegen sich mit ihren religiösen und rechtlichen Anschauungen in einer eigenartigen Sphäre jüdischer, christlicher und mohammedanischer Glaubenslehren.

Anschrift des Verfassers: Wilna, Gedimino 19

\section{[1943]}

LMAVB, F 143-1337, fol. 6r-7r

[tłumaczenie w maszynopisie]

[6r]

Przedruk specjalny z Wiadomości Geograficznych Petermannsa 1943, Zeszyt 3/4

\section{Karaimi}

przez radcę dr. Herberta Kirrinisa w Wilnie

Aż do ostatnich czasów zaszeregowanie Karaimów do wielkiej rodziny narodów, a w szczególności zestawienie ich z pokrewnymi społecznościami religijnymi, natrafiało na trudności.

Chodzi tu przytem, co należy z góry uprzedzić, nie o.jakikolwiek naród żydowski, lecz turecko-tatarski, liczący około 13.000 ludzi i walczący dziś o swe prawa do bytu.

Na Krymie zamieszkiwało przed wojną około 12.000 Karaimów, wskutek rządów bolszewickich liczba ich z pewnością zmalała. Mieszkają oni tam w większych miastach: Ewpatoria, Symferopol, Teodozja, Sewastopol, mają jednak na wsi swoją ziemię, uprawiają więc rolnictwo, ogrodnictwo ze szczególnym zamiłowaniem zajmują się sadownictwem, prowadząc przytem swego rodzaju żywot nomadów. Obok Karaimów krymskich znajduje się jeszcze dalszy 1.000 ludzi w polsko-litewskiej strefie osiedlenia. Liczba ich wynosi około $250 \mathrm{w}$ rejonie Łuck-Halicz, w samym mieście Wilnie około $250 \mathrm{i}$ w Trokach - (25 km na zachód od Wilna), centralnym punkcie Karaimów polsko-litewskich, około 350. W północnej strefie; w okolicy Poniewieża, osiągają oni liczbę około 150 głów. 
Na czele ludu karaimskiego stoi jako głowa polityczna i zarazem duchowna - Hachan, obecny Prof. Hadży Seraja Szapszał - Wilno, któremu na tym miejscu dziękuje autor za udzielone informacje.

W Wilnie Karaimi są przeważnie urzędnikami, kupcami, lub rzemieślnikami, trudnią się jednak w innych miejscowościach przede wszystkim uprawą roli: ogórki karaimskie, których nasiona przywiezione były z Krymu, są szeroko znane.

Ludzie sami wyróżniają się obcym wyglądem, przyczem wpada w oczy rys tatarsko-turecki u mężczyzn i u kobiet. Natomiast ich mieszkania i domy nie wykazują osobliwości, to samo dotyczy również ubrania. Posiadają jednak świadomość swojej tradycji i przywiązanie do swych zwyczajów i obyczajów. W muzeum karaimskim w Trokach można się bliżej zapoznać z ich materialną i duchową kulturą, a jednocześnie stwierdzić, że chodzi tu o lud, którego ojczyzną jest bliski wschód, i który należy do kultury czarnomorskiej.

Zjawienie się Karaimów w Polsce ma podstawy historyczne. Wielki przeciwnik Zakonu Krzyżackiego w bitwie grunwaldzkiej 1410 r. - wielki książę litewski Witold - dotarł w roku 1398 do brzegów Morza Czarnego. Na Krymie zażądał on od podbitej ludności jako kontrybucję wystawienia 15.000 żołnierzy, którzy, po przesiedleniu ich do zachodniej Litwy, użyci zostali jako straż graniczna przeciw Zakonowi. Ponieważ byli dobrymi płatnerzami (zbrojmistrzami) - i wykazywali w boju waleczność, - elita tych Karaimów stanowiła gwardie przyboczną wielkich książąt. W owych czasach rezydencją Witolda były Troki, w których dotrzymały się dotąd romantyczne ruiny zamku. W bezpośredniej bliskości zostali Karaimi osiedleni, otrzymali szczególne przywileje, prowadzili tam swe życie własne i aż do dzisiejszych czasów, w strefie osiedlenia polsko-litewskiego, Troki pozostały ich głównym punktem.

Karaimi są pochodzenia, tureckiego. Już wcześniej przetłumaczyli oni Biblię i swe księgi kościelne na język staro-turecki i używają ich do dziś przy odprawianiu nabożeństw. Język ten jest bardzo zbliżony do języka „Codex Cumanicus”, jedynego pozostałego pomnika mowy kumańskiej. [6v]

Oryginalną religię karaimską, w której zasady pokrótce są wytłuszczone niżej przyjęli w końcu 8 wieku między innymi Chazarzy ze swym Chaganem na czele; w państwie Chazarów, nad Morzem Czarnym, reprezentowane były również jednocześnie islam i chrześcijaństwo. Dzisiejszych. Karaimów, wyznających Stary Testament bez Talmudu i mówiących językiem staro-tureckim, należy uważać za potomków panujących niegdyś na Krymie Chazarów. Do tego już wcześniej powstałego poglądu dochodzą na podstawie szczególnie wnikliwych studiów również; historyk Krymu W. Smirnow - Simferopol 1917 i w roku 1934 wileński historyk sztuki M. Morelowski. Ostatni dotarł do tego poglądu na podstawie studiów nad geometrycznymi ornamentami na ręcznikach i innych, wyrobach tkackich. Naukowe badania karaimskich baśni i pieśni prowadza do tego samego rezultatu. 
Pomiary antropologiczne były na Karaimach już dawniej przeprowadzone, a przed paru laty dokonano również badań krwi z podziałem na grupy, przytem M. Reicher ${ }^{1}$ doszedł do rezultatu, że procentowy stosunek grupy „A” jest bardzo mały, natomiast grupy „O” bardzo wysoki, a w związku z tym do wniosku, że Karaimi stoją bardzo blisko Czuwaszów, z żydami przeto, jak to często utrzymują, nie mają nie wspólnego. Do podobnego rezultatu odnośnie pokrewieństwa Karaimów z Czuwaszami dochodzi w roku 1934 włoski profesor Gini² który badania przeprowadził w daleko obszerniejszych rozmiarach niż Reicher.

Aleksander Baszmakow (Cinquante siecles d'evolution ethnique autour de la Mer Noire, Paul Genthner, Paris 1937. = Pięćdziesiąt stuleci rozwoju etnicznego wokół Morza Czarnego) wskazuje na związki z Czerkiesami i w stosunku do nazwisk rodowych ujawniają się także wspólne więzy z Kaukazem.

Badania językowe, w szczególności polskiego profesora T. Kowalskiego, przynoszą również dane, świadczące o istniejącym pokrewieństwie pomiędzy Turkami i Karaimi. Gdy Kamal Ataturk, po wprowadzeniu do języka tureckiego alfabetu łacińskiego, zainicjował oczyszczenie mowy tureckiej ze słów obcych, pochodzących przeważnie z arabskiego i perskiego, uległo reinkorporacji do języka tureckiego 330 słów karaimskich.

Ponieważ Karaimi wyznają Stary Testament, święcą sobotę i noszą imiona ze Starego Testamentu, wyciągano często z tego wniosek, że należy ich zaliczyć do żydów. Żydzi sami jednak zajmują w tej sprawie stanowisko negatywne. W różnych leksykonach o żydowskim zabarwieniu znajdują się tylko krótkie wzmianki o Karaimach, zaś u niektórych autorów średnio- i zachodnio-europejskich utrzymuje się pogląd, że karaimizm jest tylko mało (różniącą się) zmienioną przez Anan-Ibn-Daud nauką wiary, która powstała w początku 8-go stulecia w Babilonie, jako opozycja polityczna w stosunku do ówczesnego żydostwa. W dziełach, natomiast, przeznaczonych wyłącznie, dla użytku żydostwa, utrzymują autorowie żydowscy aż do najnowszych czasów, że karaimizm nie ma nic wspólnego z nauką żydowską, natomiast stoi blisko islamu i chrześcijaństwa w zakresie wielu pojęć. W związku z tym propagowane jest w ogólności wytępienie Karaimów, których należy traktować jak odszczepieńców. „Il est permis, de les tuer" (Jest dozwolone zabijać ich).

Jak uregulowana jest religija Karaimów. Mają oni w swej nauce Pięcioksiąg i Księgę Proroków, wspólne z żydami, odrzucają jednak najistotniejszą i najważniejszą dla żydostwa drugą część wyznania wiary - Talmud. „Przepaść istniejącą miedzy tymi dwoma religjami nie da się nigdy zapełnić” (Szapszał).

1 Reicher Miche1, Sur les groupes sanguiens des Caraimes de Troki et de Wilna. Zs. Anthropologie, Prag 1932 = O grupach krwi Karaimów w Trokach i w Wilnie, Praga 1932. [Przypis oryginalny].

2 Corrado Gini: I Caraimi di Polonia e di Lituania. Zs. Genus, Roma 1936. [Przypis oryginalny]. 
Twórcy karaimizmu żyli już za czasów Chrystusa w Palestynie. Przyjmuje się przeto początek powstania tej nauki znacznie wcześniej, niż to twierdzą ży[7r] dzi, którzy w wystąpieniu. Anana Ibn-Dauda przeciw Talmudowi w 8 stuleciu upatrują jedynie odłam emancypacyjny. Karaimi natomiast upatrują w talmudystach odszczepieńców od prawdziwej wiary, nie pozwalają przeto swym współwyznawcom na żadne stosunki z nimi i pod żadnym warunkiem nie tolerują zawierania z nimi małżeństw.

Ponieważ religia karaimska jest bliżej znana szczególnie duchownym wyznania staro-greckiego, znajdujemy tu również cenne wypowiedzi, np. żyjący na emigracji metropolita Eulogiusz pisze: „Kościół ortodoksyjny uważał zawsze religię karaimską za odrębną i nie utożsamiał jej z religią żydowską. Religia karaimska uznaje Stary Testament wraz z dziesięcioma przykazaniami, które przez inne religie monoteistyczne, np. mahometańską, zostały przyjęte. Nauka karaimska uznaje Chrystusa i Mahometa za wielkich proroków i odrzuca Talmud, który stanowi fundament religii żydowskiej” (List, 5. XI. [19]41).

Przebywający obecnie za granicą metropolita Serafini wypowiada się również jak następuje: „Religia karaimska według stanowiska rosyjskiej cerkwi ortodoksyjnej jest uważana za całkiem swoistą i odrębną. Rząd rosyjski w licznych ustawach potwierdzał samodzielność religii karaimskiej i zapewniał Karaimom pełne prawa obywatelskie bez żadnych ograniczeń” (List, 25. III. [19]41).

Uwydatniało to się np. w wojskowej służbie carskiej. Karaimi krymscy dostarczali Rosji carskiej wielu oficerów. Szczególne zasługi położył w 17 stuleciu pułkownik kozaków zaporoskich. Eliasz Karaimowicz, który piastował nawet godność hetmana. To wszystko nie byłoby możliwe, o ile Karaimi byliby pochodzenia żydowskiego, ponieważ w armii carskiej potomkowie, nawet żydów wychrzczonych aż do 3-go pokolenia nie mogli zostać oficerami.

Należy również nadmienić, że religię karaimską spotykało się również wśród kozaków zaporoskich. Potomkowie ich mieszkają w stanicy Michajłowskaja, niedaleko Jekaterynodaru.

Po objęciu władzy przez Narodowy Socjalizm, żydzi poczęli się często podawać za Karaimów. Były to próba maskowania się, szkodząca Karaimom. Zarządzeniem z dnia 22. XII 1938 r. Ministerstwo Spraw Wewnętrznych Rzeszy wyjaśniło kwestie karaimską jak następuje: „Sekty Karaimów nie należy uważać za należącą do żydowskiej wspólnoty religijnej. Twierdzenie, że Karaimi w ogólności są pokrewni żydom, nie może być przyjęte, ponieważ przynależność rasowa danej osoby nie pozwala się określić li tylko według jej przynależności do danego narodu, lecz winny być tu wzięte pod uwagę osobiste okoliczności rodowe i cechy rasowo-biologiczne".

Odpowiada to negatywnemu stosunkowi Karaimów do żydów; próby przeto wywodzenia Karaimów od żydów, pomimo ich przednioazjatyckich właściwości, byłyby błędne. Należą oni do ludów turecko-tatarskich, z których niektóre 
odłamy wskutek burz dziejowych w Europie wschodniej przyniesione zostały aż na teren osiedlenia polsko-litewskiego i obracają się ze swymi religijnymi i prawnymi światopoglądami w jedynej swego rodzaju sferze wierzeń religijnych chrześcijańskich, żydowskich i mahometańskich.

Adres autora: Wilno, Gedimino 32 